\title{
Accumulation and Distribution of Natural Gas Reservoir in Volcanic Active Area: A Case Study of the Cretaceous Yingcheng Formation in the Dehui Fault Depression, Songliao Basin, NE China
}

\author{
Fancheng Zeng, ${ }^{1,2}$ Bo Liu $\mathbb{D}^{1},{ }^{1,3}$ Changmin Zhang,, Guoyi Zhang, ${ }^{2}$ Jin Gao, ${ }^{2}$ Junjie Liu, \\ and Mehdi Ostadhassan ${ }^{3}$ \\ ${ }^{1}$ Yangtze University, Wuhan, Hubei Province 434100, China \\ ${ }^{2}$ Company of Jilin Oilfield, Songyuan, Jilin Province 138000, China \\ ${ }^{3}$ Northeast Petroleum University, Daqing, Heilongjiang Province 163318, China \\ Correspondence should be addressed to Bo Liu; liubo6869@163.com
}

Received 16 July 2021; Accepted 4 September 2021; Published 30 September 2021

Academic Editor: Chenhao Sun

Copyright (c) 2021 Fancheng Zeng et al. This is an open access article distributed under the Creative Commons Attribution License, which permits unrestricted use, distribution, and reproduction in any medium, provided the original work is properly cited.

\begin{abstract}
Tight gas sandstone and volcanic gas reservoirs have received global attention in the energy arena for further exploration and exploitation attempts. Considering the Yingcheng Formation of Dehui fault depression in the Songliao Basin as an example, this study focused on the accumulation and distribution of natural gas reservoirs in volcanic area in a fault depression basin. Volcanic activities occurred in the Yingcheng Formation, which is distributed centrally in the northwest of the study area. During the sedimentation of the Yingcheng Formation, fan-delta, lacustrine, and nearshore subaqueous fan facies were deposited. The source rocks of the Yingcheng Formation have high abundance of organic matter mainly in type III at high-overmature stages, indicating favorable conditions for gas production. The porosity of volcanic reservoir is $3.0 \%-14.8 \%$, the permeability is $0.0004 \mathrm{mD}-2.52 \mathrm{mD}$, and the pore types are mainly secondary dissolved pores and fractures. Besides, the porosity of the tight sandstone reservoir is $0.5 \%-11.2 \%$, and the permeability is $0.0008 \mathrm{mD}-3.17 \mathrm{mD}$. The pore types are mainly interparticle pores, with a small proportion of intraparticle pores and microfractures. The intrusion of late volcanic magma provided sufficient heat for the thermal maturity progression of organic matter in Yingcheng Formation and promoted the generation of natural gas in large quantities. Volcanic rocks formed at the early and middle stages of volcanic activities occupied the sedimentary space and hindered the development of sedimentary sand bodies to a certain extent. However, volcanic rocks can become the seal to promote the formation of tight sandstone gas traps. Comparing tight sandstone reservoirs with volcanic ones, the latter are less affected by compaction; thus, their petrophysical properties do not vary much with depth, showing more homogeneous characteristics. The pyroclastic rocks influenced by volcanic activity and the secondary pores formed by dissolution in the later stages also provide reservoir space for gas accumulation. Ultimately, the tight sandstone and volcanic rocks in the study area form a complex gas reservoir system, which can become a reference for exploration and exploitation of natural gas in other petroliferous fault depressions that are affected by volcanisms.
\end{abstract}

\section{Introduction}

IEA [1] estimates that global tight gas sandstone resources are roughly $209.6 \times 10^{12} \mathrm{~m}^{3}$. Additionally, exploration and development of tight gas sandstone reservoirs has supported the driving force for increasing global natural gas production in recent years [2]. In China, huge tight sandstone gas reservoirs exist in major oil-bearing basins, including the Tarim, Ordos, and Songliao Basins [3, 4]. As of 2016, gas production from tight sandstone reservoirs has reached $330 \times 10^{8} \mathrm{~m}^{3}$, accounting for one-quarter of China's annual natural gas production [3]. In this regard, volcanic gas reservoirs have also 


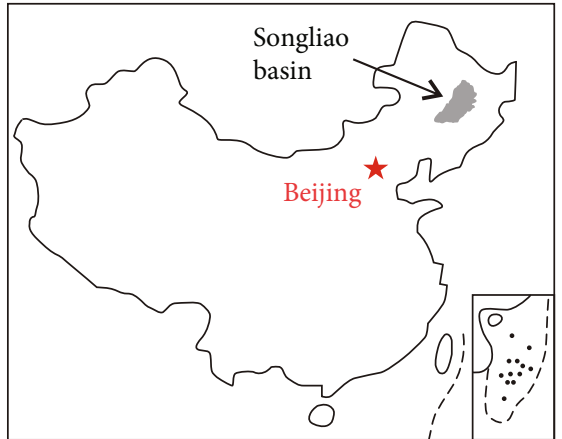

(a)

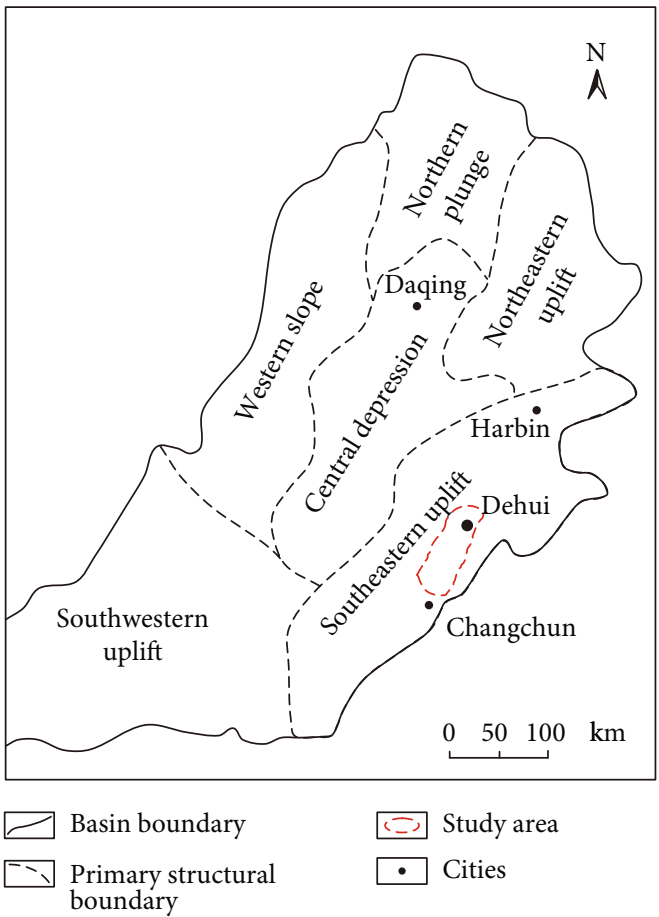

(b)

Figure 1: Continued. 


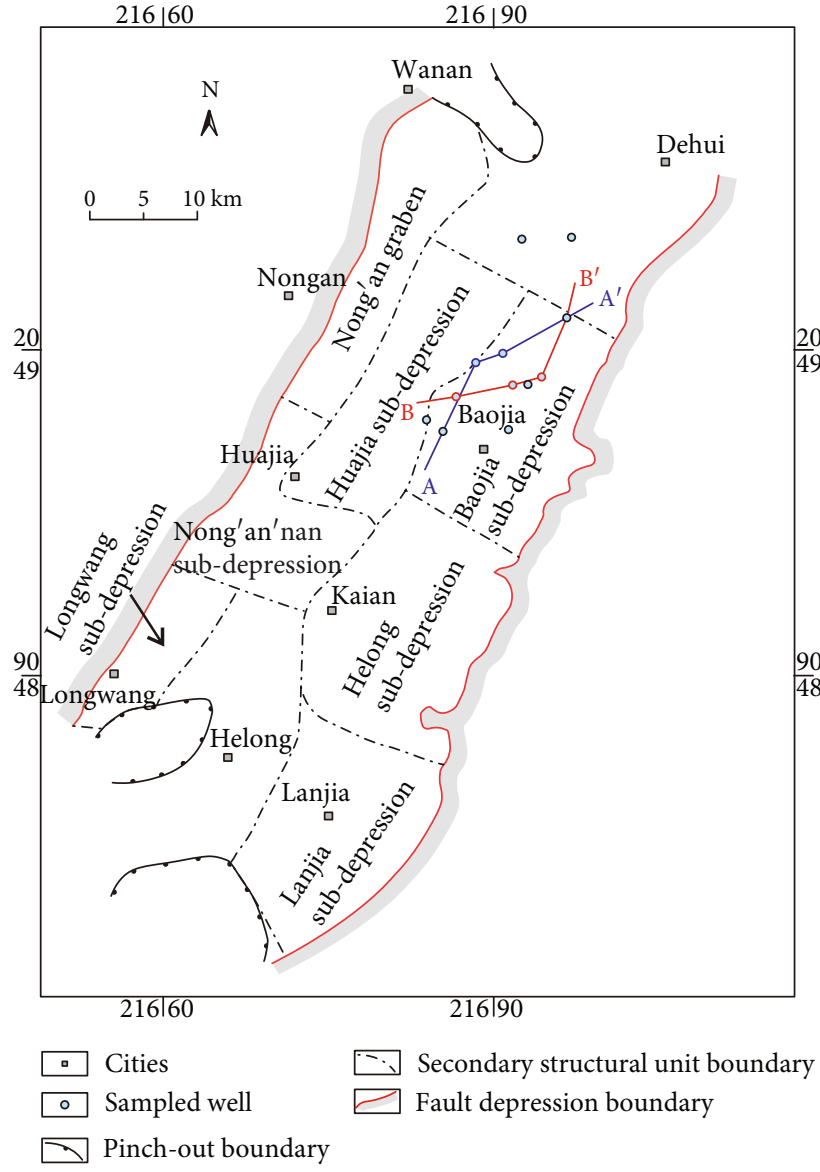

(c)

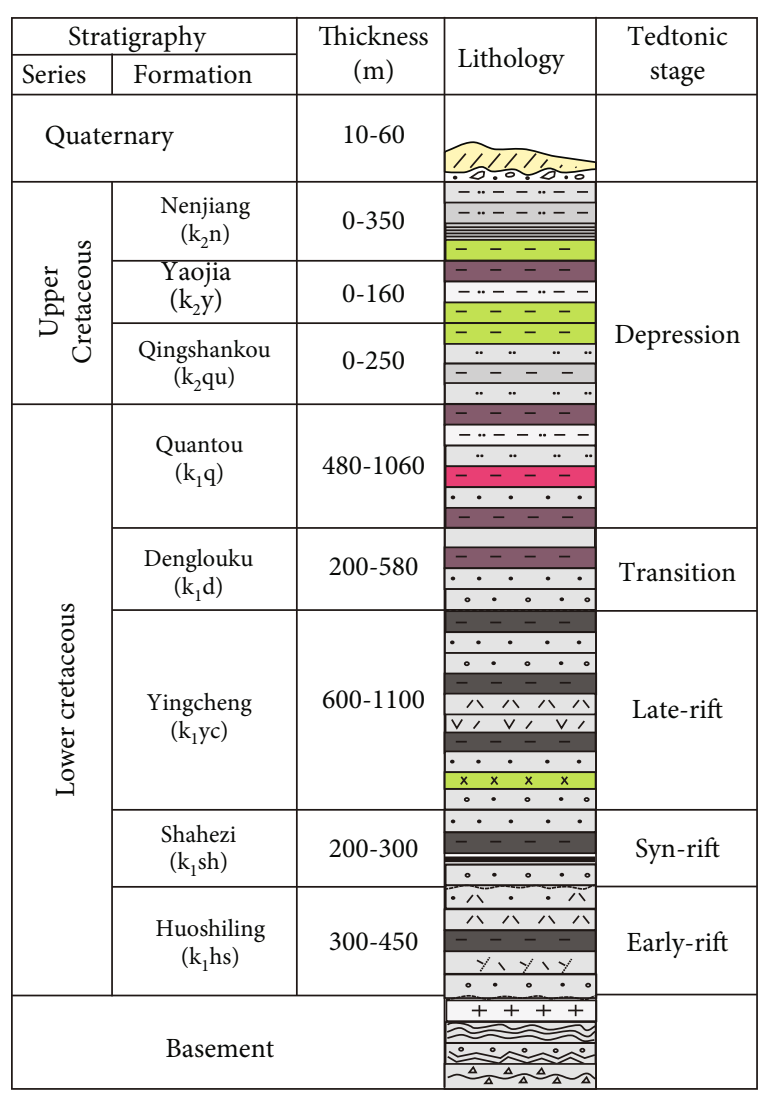

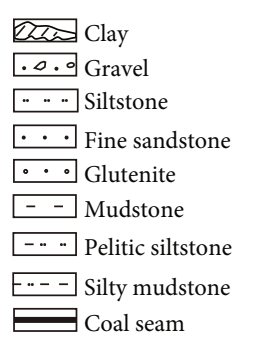

\begin{tabular}{|c|c|}
\hline$v / v$ & Dacite \\
\hline ハ八 & Tuff \\
\hline$\cdot$ ・・・ & Tuffaceous sandstone \\
\hline \begin{tabular}{|lll}
$x$ & $x$ & $x$ \\
\end{tabular} & Diabase \\
\hline YYy & Rhyolite \\
\hline+++ & Granite \\
\hline$\approx$ & Schist \\
\hline 办 & Metamorphic conglomerate \\
\hline 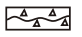 & Quartz schist \\
\hline
\end{tabular}

(d)

Figure 1: (a) Geographic location of the Songliao Basin. (b) Location of Dehui Depression in the Southern Songliao Basin. (c) Tectonic units of the Dehui Depression. (d) Generalized Mesozoic-Cenozoic stratigraphy of the Dehui depression, showing the formation thickness, lithology, and stage of tectonic evaluation.

been found sporadically where tight sandstone gas reservoirs are abundant, such as the Lower Cretaceous in the Songliao Basin, the Jurassic in the Hailaer Basin, and the Upper Paleozoic of the Ordos Basin. The tight gas sandstone reservoirs and volcanic gas reservoirs in the volcanically active areas together constitute a complex gas accumulation system which requires further investigation [5-8].

In basins located on the eastern China, volcanosedimentary sequences have been widely developed since the Late Mesozoic [7]. During volcanism, a large number of igneous formations were formed, accompanied by various clastic deposits from igneous materials and volcanic lacustrine deposits during the intercalation period, forming an interactive sedimentary sequence [9]. In addition to the creation of these volcanic reservoirs, volcanic activity also has had an impact on the accumulation of natural gas in tight sandstones regionally [10]. Moreover, the influence of volca- nisms on the basin sedimentation manifests itself in the following ways: first, volcanic activity can be used as a regional provenance, providing supply for the basin sedimentation $[11,12]$. However, such volcanic activities in the island arc belt not only would change the composition of the supply in the sedimentary system but also play a role in blocking the distribution of the sedimentary system, alter topography, promote the formation or migration of the basin depocenter, develop around it, and thus form a new sedimentary system. Secondly, volcanic activity is also an important event that impacts the basin accommodation. Due to rapid accumulation of volcanic eruptions in some areas, the basin is affected by the thermal subsidence, and somehow, this was accelerated regionally, causing the total water volume to decrease. Conversely, in other areas of the depression, the influence of volcanic activities has been weak; therefore, the change of accommodative space is not significant [13]. This means 


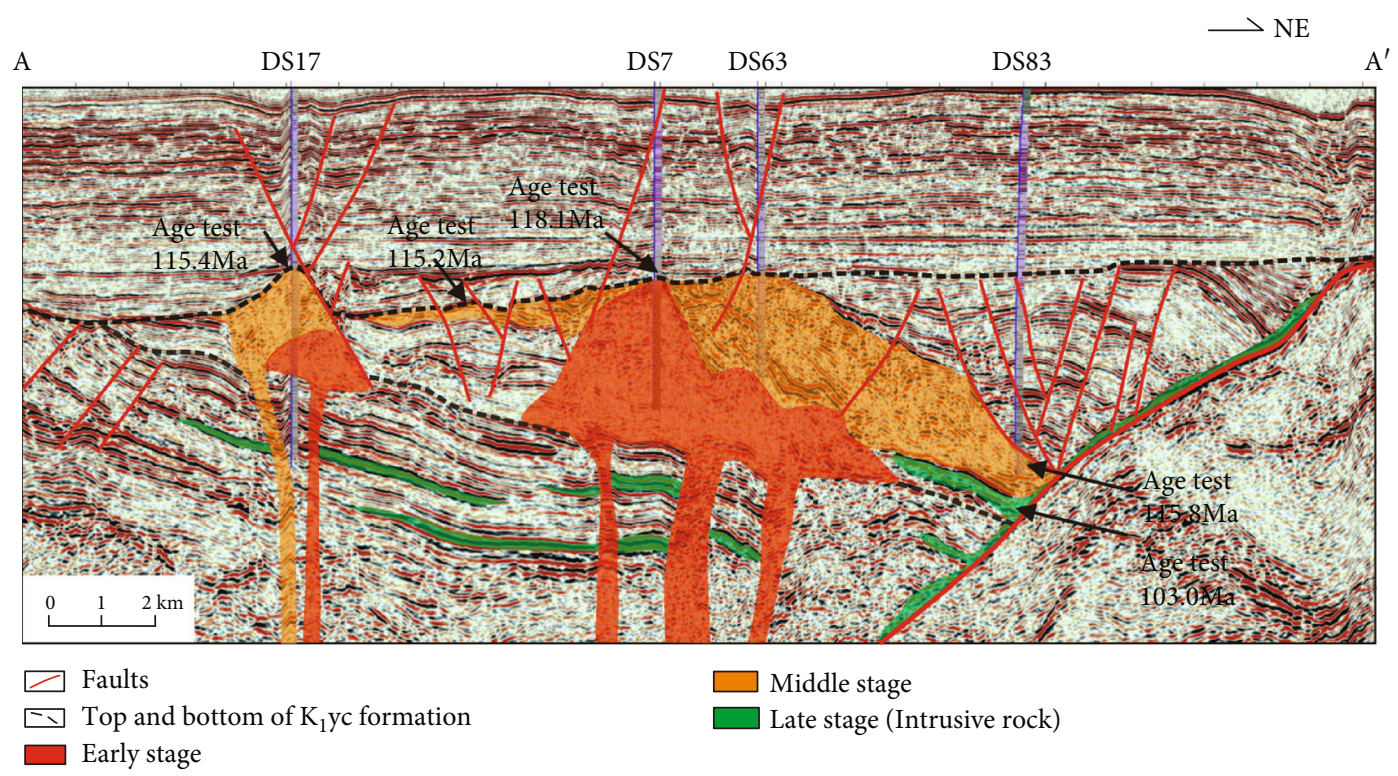

Figure 2: The seismic profile shows the volcanic activity of the $\mathrm{K}_{1} \mathrm{yc}$ in the Dehui Depression; location of the profile is shown in Figure 1 (modified from [28]).

the overall accommodative space for sediment load varies regionally throughout the basin. In addition, volcanic activities are often accompanied by large-scale hydrothermal events where high temperature as well as high pressure hydrothermal flux upwashes and enters the strata. As a result, this hydrothermal fluid contains rich soluble ions and will have persistent effects of detrital (mineral), which makes its diagenetic intensity to be strong [14]. In addition to the impact of volcanic activities that explained how would influence sedimentation in the basin, syndepositional volcanism controls the development of reservoirs mainly by providing soluble components and promoting the formation of fractures [15]. This has happened via the dissolution of chemically unstable soluble pyroclastic components that were preserved in the adjacent sedimentary sand bodies within the pores during the middle to late burial stages. Furthermore, during the periods of volcanic activity, the influx of a large amount of magma flew into the sedimentary sequence that resulted in the brittle rupture of consolidated sandstone to form microfractures, which increased the reservoir space and permeability of the reservoir $[16,17]$.

In such events, volcanic ash would be beneficial to the enrichment and preservation of organic matter [18, 19] and promotes the conversion of organic matter to hydrocarbons [20-22]. These were some positive impacts of volcanic activities on various components of the petroleum system; however, its destructive effects on hydrocarbon accumulation cannot be neglected either. For example, volcanic activities can disrupt oil and gas accumulation significantly by creating channels or associated faults to damage the integrity of the trap and creating seepages for the accumulated hydrocarbons to escape the reservoir [17]. In addition, the heat source provided by volcanic activity also causes dehydration of minerals containing crystalline water in the adjacent sediments to recrystallize, which would fill the pores and fractures, reducing connectivity and deteriorating reservoir petrophysical properties.
Songliao Basin is a large petroliferous basin developed on the basement of the Upper Paleozoic metamorphic rock series. During the rift period, there were intense tectonic movements and frequent volcanic activities. However, the combination of volcanism and sedimentation created good conditions for the formation of oil and gas reservoirs [23, 24]. In recent years, several large tight natural gas reservoirs have been discovered in the Songliao Basin [25], while some are associated with the volcanic rocks of the basin $[6,26,27]$. In the Dehui fault depression that is the subject of this study, both major tight sandstone and volcanic gas reservoirs are found in the Cretaceous strata, with great potential for resources and are good exploration prospects.

In this study, tight gas sandstone and volcanic gas reservoir influenced by the volcanic activity of the Yingcheng Formation in the Dehui fault depression of the southern Songliao Basin has been assessed. By systematically sampling the source rocks, volcanic rocks, and tight sandstones in the study area and analyzing and examining them for total organic carbon (TOC) content, vitrinite reflectance (Ro), and reservoir physical property (porosity and permeability), the geochemical characteristics of the source rocks and the petrophysical properties of the reservoir rock including the volcanic and tight sandstone are understood. The goal of this study is to analyze the effects of volcanic activity in the area on the accumulation of natural gas. Furthermore, we comprehensively investigated the complexity of the petroleum system that is formed in the volcanosedimentary sequence, to provide reference for the exploration and prospect evaluation in this petroliferous basin for future developments.

\section{Geologic Setting}

2.1. Location and Stratigraphy. The Dehui fault depression is located in the southeast uplift of the Songliao Basin 


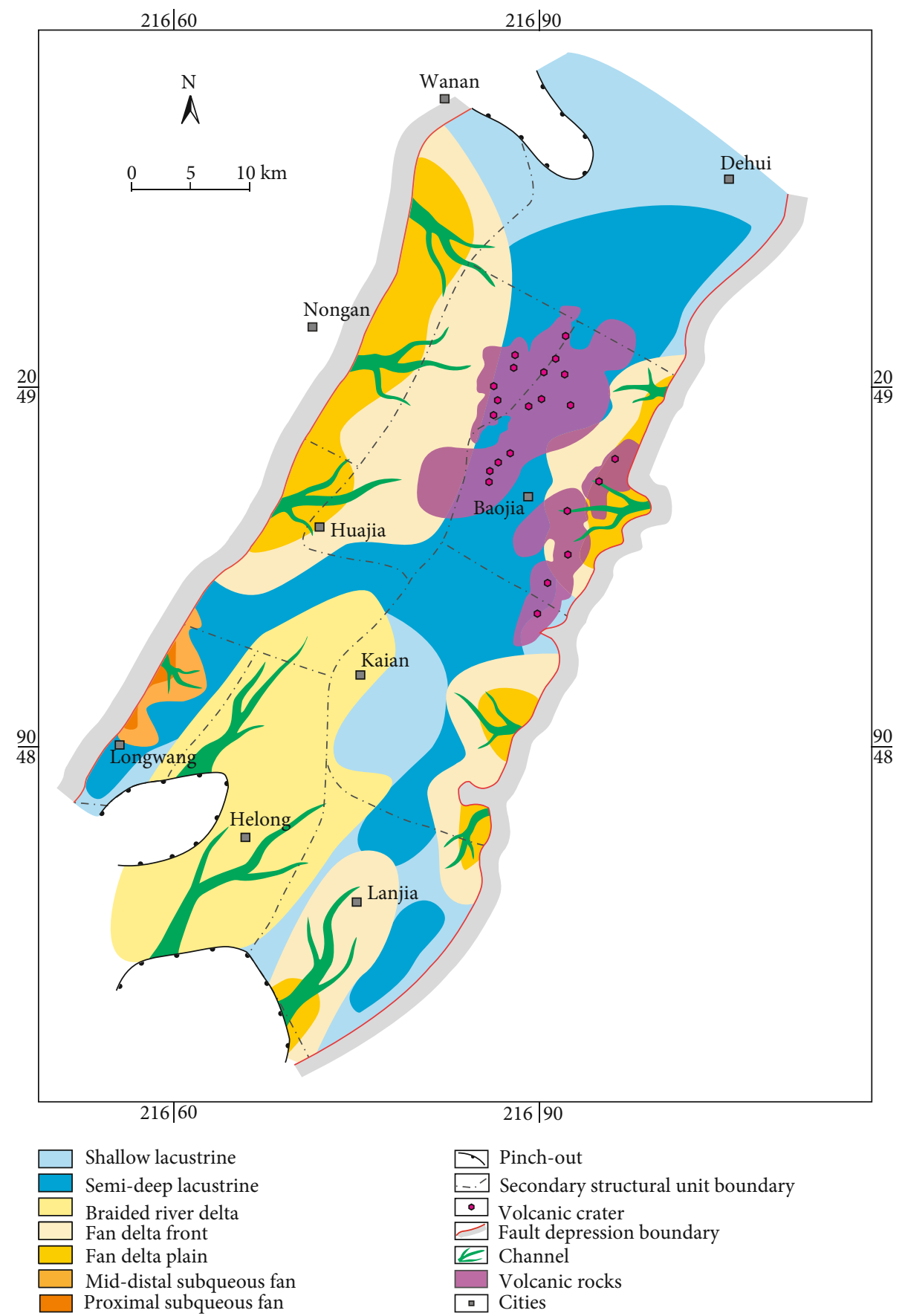

Figure 3: The sedimentary facies map of the $\mathrm{K}_{1} \mathrm{yc}$ in the Dehui Depression shows the distribution of volcanic and sedimentary rocks.

(Figure 1(a); [5]). It is a sedimentary fault depression with synrift and thermal subsidence double-layered structure developed on the basement of Upper Paleozoic metamorphic rock series, covering an area of $4053 \mathrm{~km}^{2}$ (Figure 1(b)). The fault depression generally presents an NNE trending double fault-controlled graben, which is cut by NNE trending faults, forming a structural pattern of horst-graben-steps. It can be further divided into seven secondary structural units, including the Nong'an Graben, Huajia Subdepression, Baojia Subdepression, Nong'an'nan Subdepression, Helong Subdepression, Lanjia Subdepression, and Longwang Subdepression (Figure 1(c)).
Since the Mesozoic, the fault depression has undergone several tectonic activities of subsidence and uplift, and the Mesozoic and Cenozoic strata with a thickness of more than $5000 \mathrm{~m}$ have been deposited [23]. The strata developed from bottom to top in this area are the Carboniferous-Permian basement, the lower Cretaceous Huoshiling Formation $\left(\mathrm{K}_{1} \mathrm{hs}\right)$, Shahezi Formation $\left(\mathrm{K}_{1} \mathrm{sh}\right)$, Yingcheng Formation $\left(K_{1} y c\right)$, Denglouku Formation $\left(K_{1} d\right)$, Quantou Formation $\left(\mathrm{K}_{1} \mathrm{q}\right)$, the upper Cretaceous Qingshankou Formation $\left(\mathrm{K}_{2} \mathrm{qn}\right)$, Yaojia Formation $\left(\mathrm{K}_{2} \mathrm{y}\right)$, Nenjiang Formation $\left(\mathrm{K}_{2} \mathrm{n}\right)$, and Quaternary (Figure $1(\mathrm{~d})$ ), among which the Yingcheng Formation is the target layer of this study. 
TABle 1: Results of Rock-Eval pyrolysis.

\begin{tabular}{|c|c|c|c|c|c|c|c|}
\hline Depth $(\mathrm{m})$ & TOC $(\%)$ & $S_{1}(\mathrm{mg} / \mathrm{g})$ & $S_{2}(\mathrm{mg} / \mathrm{g})$ & $T_{\max }\left({ }^{\circ} \mathrm{C}\right)$ & $S_{1}+S_{2}(\mathrm{mg} / \mathrm{g})$ & HI (mg HC/g TOC) & PI \\
\hline 2856.60 & 2.28 & 2.53 & 1.85 & 486.00 & 4.38 & 81.14 & 0.58 \\
\hline 2856.65 & 3.24 & 0.63 & 1.57 & 490.00 & 2.20 & 48.46 & 0.29 \\
\hline 2857.00 & 2.67 & 1.11 & 1.58 & 490.00 & 2.69 & 59.18 & 0.41 \\
\hline 2857.35 & 2.02 & 0.36 & 1.05 & 489.00 & 1.41 & 51.98 & 0.26 \\
\hline 2857.70 & 3.19 & 0.94 & 1.86 & 489.00 & 2.80 & 58.31 & 0.34 \\
\hline 2858.20 & 2.43 & 0.65 & 1.31 & 491.00 & 1.96 & 53.91 & 0.33 \\
\hline 2858.70 & 3.03 & 0.73 & 1.63 & 489.00 & 2.36 & 53.80 & 0.31 \\
\hline 2859.49 & 1.96 & 0.81 & 2.47 & 488.00 & 3.28 & 126.02 & 0.25 \\
\hline 2859.50 & 1.69 & 0.51 & 0.95 & 490.00 & 1.46 & 56.21 & 0.35 \\
\hline 2860.00 & 2.06 & 0.54 & 1.06 & 488.00 & 1.60 & 51.46 & 0.34 \\
\hline 2860.70 & 3.33 & 0.29 & 0.68 & 490.00 & 0.97 & 20.42 & 0.30 \\
\hline 2861.40 & 0.22 & 0.02 & 0.14 & 482.00 & 0.16 & 63.64 & 0.13 \\
\hline 2861.90 & 2.18 & 0.52 & 1.24 & 488.00 & 1.76 & 56.88 & 0.30 \\
\hline 2862.20 & 2.12 & 0.33 & 0.96 & 489.00 & 1.29 & 45.28 & 0.26 \\
\hline 2862.70 & 2.12 & 0.53 & 1.08 & 490.00 & 1.61 & 50.94 & 0.33 \\
\hline 2863.30 & 2.12 & 0.39 & 1.28 & 488.00 & 1.67 & 60.38 & 0.23 \\
\hline 2863.80 & 2.17 & 0.36 & 1.14 & 490.00 & 1.50 & 52.53 & 0.24 \\
\hline 2864.00 & 2.13 & 0.23 & 1.18 & 487.00 & 1.41 & 55.40 & 0.16 \\
\hline 2864.40 & 2.39 & 0.38 & 1.20 & 490.00 & 1.58 & 50.21 & 0.24 \\
\hline 2864.90 & 1.40 & 0.14 & 0.68 & 489.00 & 0.82 & 48.57 & 0.17 \\
\hline 2865.20 & 1.59 & 0.23 & 0.87 & 488.00 & 1.10 & 54.72 & 0.21 \\
\hline 2865.70 & 3.10 & 0.61 & 1.77 & 490.00 & 2.38 & 57.10 & 0.26 \\
\hline 2866.20 & 1.97 & 0.40 & 1.08 & 490.00 & 1.48 & 54.82 & 0.27 \\
\hline 2866.80 & 1.95 & 0.22 & 1.02 & 488.00 & 1.24 & 52.31 & 0.18 \\
\hline 2867.00 & 2.19 & 0.31 & 1.19 & 488.00 & 1.50 & 54.34 & 0.21 \\
\hline 2867.20 & 2.00 & 0.39 & 1.00 & 488.00 & 1.39 & 50.00 & 0.28 \\
\hline 2867.90 & 1.40 & 0.26 & 0.87 & 487.00 & 1.13 & 62.14 & 0.23 \\
\hline 2868.20 & 1.80 & 0.43 & 0.99 & 488.00 & 1.42 & 55.00 & 0.30 \\
\hline 2868.70 & 1.77 & 0.35 & 0.98 & 487.00 & 1.33 & 55.37 & 0.26 \\
\hline 2869.40 & 3.18 & 0.46 & 1.80 & 489.00 & 2.26 & 56.60 & 0.20 \\
\hline 2869.70 & 1.26 & 0.14 & 0.72 & 488.00 & 0.86 & 57.14 & 0.16 \\
\hline 2870.20 & 1.16 & 0.22 & 0.66 & 489.00 & 0.88 & 56.90 & 0.25 \\
\hline 2870.50 & 1.30 & 0.11 & 0.72 & 488.00 & 0.83 & 55.38 & 0.13 \\
\hline 2885.50 & 2.74 & 0.68 & 1.53 & 490.00 & 2.21 & 55.84 & 0.31 \\
\hline 3053.95 & 1.69 & 0.35 & 1.87 & 484.00 & 2.22 & 110.65 & 0.16 \\
\hline 3056.00 & 0.78 & 0.22 & 0.61 & 494.00 & 0.83 & 78.21 & 0.27 \\
\hline 3056.25 & 2.08 & 0.25 & 1.23 & 495.00 & 1.48 & 59.13 & 0.17 \\
\hline 3057.55 & 0.85 & 0.24 & 1.09 & 396.00 & 1.33 & 128.24 & 0.18 \\
\hline 3057.85 & 0.58 & 0.03 & 0.39 & 488.00 & 0.42 & 67.24 & 0.07 \\
\hline 3059.38 & 0.22 & 0.01 & 0.15 & 488.00 & 0.16 & 68.18 & 0.06 \\
\hline 3060.45 & 0.38 & 0.04 & 1.07 & 456.00 & 1.11 & 281.58 & 0.04 \\
\hline 3063.14 & 1.13 & 0.08 & 1.50 & 472.00 & 1.58 & 132.74 & 0.05 \\
\hline 3063.43 & 1.73 & 0.16 & 2.72 & 462.00 & 2.88 & 157.23 & 0.06 \\
\hline 3065.50 & 0.76 & 0.08 & 1.46 & 443.00 & 1.54 & 192.11 & 0.05 \\
\hline 3377.98 & 1.40 & 0.06 & 0.42 & 519.00 & 0.48 & 30.00 & 0.13 \\
\hline 3395.94 & 0.61 & 0.04 & 0.47 & 487.00 & 0.51 & 77.05 & 0.08 \\
\hline 3396.90 & 0.62 & 0.05 & 0.41 & 493.00 & 0.46 & 66.13 & 0.11 \\
\hline
\end{tabular}


TABle 1: Continued.

\begin{tabular}{|c|c|c|c|c|c|c|c|}
\hline Depth $(\mathrm{m})$ & TOC (\%) & $S_{1}(\mathrm{mg} / \mathrm{g})$ & $S_{2}(\mathrm{mg} / \mathrm{g})$ & $T_{\max }\left({ }^{\circ} \mathrm{C}\right)$ & $S_{1}+S_{2}(\mathrm{mg} / \mathrm{g})$ & $\mathrm{HI}$ (mg HC/g TOC) & PI \\
\hline 2306.00 & 1.51 & 2.20 & 1.15 & 458.00 & 3.35 & 76.16 & 0.66 \\
\hline 2307.00 & 1.83 & 6.95 & 1.18 & 505.00 & 8.13 & 64.48 & 0.85 \\
\hline 2316.00 & 0.34 & 1.90 & 0.34 & 387.00 & 2.24 & 100.00 & 0.85 \\
\hline 2326.00 & 0.34 & 2.33 & 0.33 & 385.00 & 2.66 & 97.06 & 0.88 \\
\hline 2820.00 & 0.51 & 1.06 & 0.35 & 485.00 & 1.41 & 68.63 & 0.75 \\
\hline 2850.00 & 0.51 & 0.91 & 0.31 & 484.00 & 1.22 & 60.78 & 0.75 \\
\hline 2890.00 & 0.43 & 1.93 & 0.36 & 486.00 & 2.29 & 83.72 & 0.84 \\
\hline 2910.00 & 3.84 & 4.50 & 2.83 & 487.00 & 7.33 & 73.70 & 0.61 \\
\hline 2920.00 & 3.33 & 3.66 & 2.23 & 486.00 & 5.89 & 66.97 & 0.62 \\
\hline 2930.00 & 2.72 & 2.74 & 1.80 & 488.00 & 4.54 & 66.18 & 0.60 \\
\hline 2940.00 & 4.24 & 1.19 & 2.64 & 489.00 & 3.83 & 62.26 & 0.31 \\
\hline 2960.00 & 6.82 & 1.94 & 6.47 & 485.00 & 8.41 & 94.87 & 0.23 \\
\hline 2980.00 & 5.94 & 1.43 & 5.19 & 485.00 & 6.62 & 87.37 & 0.22 \\
\hline 3005.00 & 8.33 & 2.76 & 8.62 & 485.00 & 11.38 & 103.48 & 0.24 \\
\hline 3020.00 & 1.64 & 1.29 & 1.23 & 488.00 & 2.52 & 75.00 & 0.51 \\
\hline 3035.00 & 1.56 & 1.68 & 1.04 & 490.00 & 2.72 & 66.67 & 0.62 \\
\hline 3217.54 & 1.60 & 0.10 & 0.49 & 513.00 & 0.59 & 30.63 & 0.17 \\
\hline 3677.60 & 1.28 & 0.14 & 0.49 & 570.00 & 0.63 & 38.28 & 0.22 \\
\hline 2665.00 & 2.50 & 3.35 & 2.76 & 465.00 & 6.11 & 110.40 & 0.55 \\
\hline 2680.00 & 12.90 & 4.31 & 17.22 & 472.00 & 21.53 & 133.49 & 0.20 \\
\hline 2685.00 & 3.53 & 2.80 & 3.59 & 473.00 & 6.39 & 101.70 & 0.44 \\
\hline 2690.00 & 8.42 & 3.56 & 9.97 & 473.00 & 13.53 & 118.41 & 0.26 \\
\hline 2710.00 & 17.78 & 4.25 & 24.81 & 473.00 & 29.06 & 139.54 & 0.15 \\
\hline 2725.00 & 9.65 & 6.85 & 16.05 & 475.00 & 22.90 & 166.32 & 0.30 \\
\hline 2880.00 & 2.06 & 1.01 & 1.73 & 483.00 & 2.74 & 83.98 & 0.37 \\
\hline 2898.00 & 2.32 & 1.59 & 1.84 & 485.00 & 3.43 & 79.31 & 0.46 \\
\hline 2940.00 & 5.51 & 6.42 & 4.99 & 488.00 & 11.41 & 90.56 & 0.56 \\
\hline 2970.00 & 1.84 & 4.88 & 1.50 & 488.00 & 6.38 & 81.52 & 0.76 \\
\hline 2990.00 & 1.93 & 5.08 & 1.68 & 492.00 & 6.76 & 87.05 & 0.75 \\
\hline 3010.00 & 4.82 & 4.18 & 4.19 & 489.00 & 8.37 & 86.93 & 0.50 \\
\hline 3015.00 & 18.85 & 7.79 & 16.80 & 489.00 & 24.59 & 89.12 & 0.32 \\
\hline 3020.00 & 18.71 & 6.71 & 14.31 & 491.00 & 21.02 & 76.48 & 0.32 \\
\hline 3060.00 & 3.93 & 12.59 & 3.42 & 493.00 & 16.01 & 87.02 & 0.79 \\
\hline 3078.00 & 13.46 & 14.75 & 13.15 & 492.00 & 27.90 & 97.70 & 0.53 \\
\hline 3215.00 & 3.82 & 10.34 & 2.26 & 504.00 & 12.60 & 59.16 & 0.82 \\
\hline 3420.00 & 2.00 & 0.07 & 0.46 & 434.00 & 0.53 & 23.00 & 0.13 \\
\hline 3830.00 & 7.08 & 9.53 & 8.45 & 483.00 & 17.98 & 119.35 & 0.53 \\
\hline 2785.00 & 3.18 & 20.92 & 3.06 & 356.00 & 23.98 & 96.23 & 0.87 \\
\hline 2795.00 & 2.88 & 18.55 & 2.72 & 351.00 & 21.27 & 94.44 & 0.87 \\
\hline 2805.00 & 3.22 & 21.38 & 3.30 & 357.00 & 24.68 & 102.48 & 0.87 \\
\hline 2815.00 & 3.20 & 17.15 & 3.21 & 360.00 & 20.36 & 100.31 & 0.84 \\
\hline 2825.00 & 3.39 & 19.15 & 3.11 & 358.00 & 22.26 & 91.74 & 0.86 \\
\hline 2835.00 & 3.56 & 23.33 & 3.40 & 364.00 & 26.73 & 95.51 & 0.87 \\
\hline 2845.00 & 3.30 & 18.99 & 3.41 & 364.00 & 22.40 & 103.33 & 0.85 \\
\hline 2855.00 & 3.15 & 16.83 & 3.14 & 363.00 & 19.97 & 99.68 & 0.84 \\
\hline 2865.00 & 3.16 & 11.40 & 2.66 & 344.00 & 14.06 & 84.18 & 0.81 \\
\hline
\end{tabular}


TABLE 1: Continued.

\begin{tabular}{|c|c|c|c|c|c|c|c|}
\hline Depth $(\mathrm{m})$ & TOC (\%) & $S_{1}(\mathrm{mg} / \mathrm{g})$ & $S_{2}(\mathrm{mg} / \mathrm{g})$ & $T_{\max }\left({ }^{\circ} \mathrm{C}\right)$ & $S_{1}+S_{2}(\mathrm{mg} / \mathrm{g})$ & HI (mg HC/g TOC) & PI \\
\hline 2870.00 & 2.78 & 6.64 & 1.63 & 329.00 & 8.27 & 58.63 & 0.80 \\
\hline 2878.00 & 2.59 & 11.15 & 2.35 & 344.00 & 13.50 & 90.73 & 0.83 \\
\hline 2885.00 & 3.97 & 14.08 & 3.09 & 493.00 & 17.17 & 77.83 & 0.82 \\
\hline 2890.00 & 3.34 & 21.38 & 2.87 & 341.00 & 24.25 & 85.93 & 0.88 \\
\hline
\end{tabular}

TOC: total organic carbon content; $S_{1}$ : free hydrocarbons present in the rock; $S_{2}$ : petroleum generated by pyrolysis; $S_{1}+S_{2}:$ genetic potential; $T_{\text {max }}$ : the temperature at peak evolution of $S_{2}$ hydrocarbons $\left({ }^{\circ} \mathrm{C}\right)$; HI: hydrogen index, $S_{2}$ divided by TOC $\times 100$; PI: production index, $S_{1} /\left(S_{1}+S_{2}\right)$.

2.2. Volcanic Activities. During the period of the Yingcheng Formation deposition, numerous volcanic activities happened, leading to the creation of faults in Dehui fault depression [28]. By employing the superposition relationship between volcanic rock mass from 3D seismic data and zircon dating, three periods of volcanic activities in this area were recognized, which first increased and then gradually weakened. During the initial stages of volcanic activity, eruptions mainly occurred at the edge of the depression and near the faults which controlled the depression. Large volcanic groups developed, and later, sedimentary strata covered the volcanic rocks [5]. Drilling through these volcanic rocks confirmed mushroom-like structures with obvious volcanic channels dated $118 \mathrm{Ma}$, which marks the onset of the Yingcheng Formation. The middle stage of the volcanic activity is dominated by eruption of pyroclastic facies and magma flows along the volcanic channels and faults that were formed during the first stage of volcanism forming a large area of pyroclastic shield. This period is dated back to $115 \mathrm{Ma}$, which represents the middle stage of the creation of the Yingcheng Formation. Finally, in the late period of volcanic activity, volcanic intrusions were formed, and because of its weakened energy, the magma could not reach the surface and only cut through the strata. This took place about $103 \mathrm{Ma}$, which coincides with the depositional period of the Denglouku Formation (Figure 2; [28]).

2.3. Sedimentary Facies. During the deposition of the Yingcheng Formation, the Songliao Basin was tectonically active, and a number of faults were developed. The Yingcheng Formation is divided into two members while the first member is strongly affected by volcanism, and a large set of volcanic formations are developed around the Dehui fault depression [5]. At the margins of the fault depression, a set of fan-delta and lacustrine facies were deposited, and a mixed sequence of volcanic and clastic sedimentary strata was formed. The sedimentary facies in the study area are mainly fan-deltaic, lacustrine, and nearshore subaqueous fan (Figure 3). The fan-delta is widely developed in the eastern and western margins of the depression, while the braided river delta plain is dominant in the south, and the lacustrine facies center is located in the northeast of the depression. During the sedimentation process, the supply of sediment was hindered by the influence of multiple volcanic activities, which limited the range and thickness of sand bodies that were deposited in the northeast.

2.4. Petroleum System. Three sets of petroleum sourcereservoir-seal systems are identified in the study area $[5$,

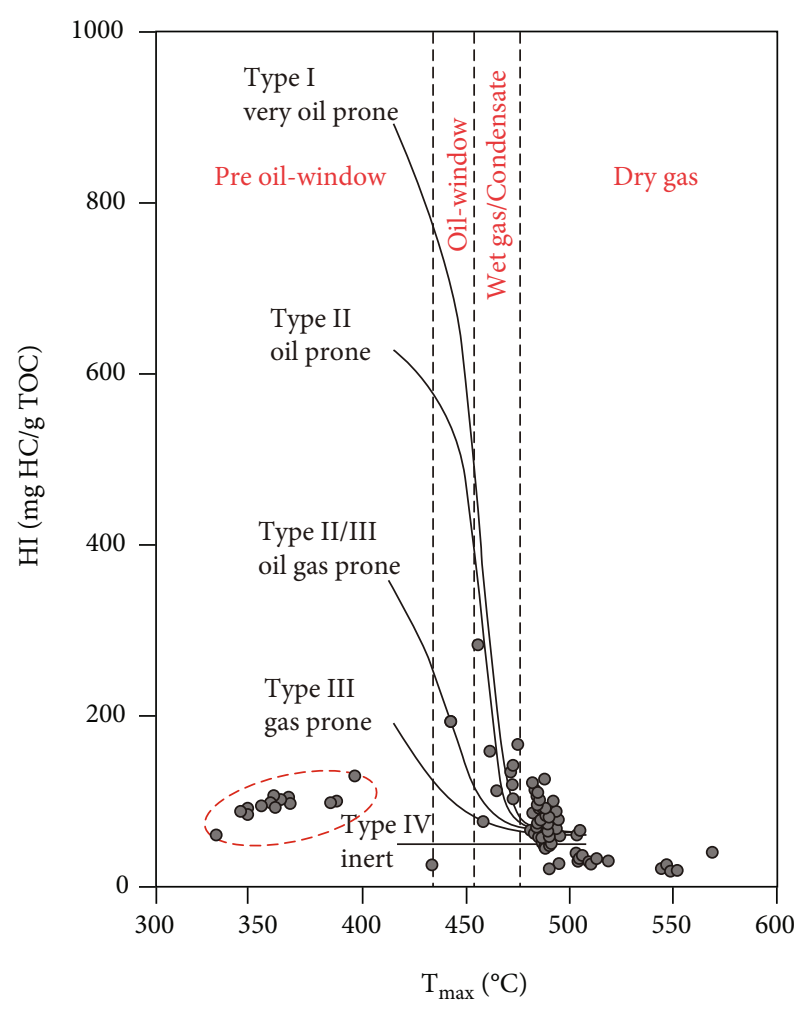

Figure 4: Plot of TOC (wt.\%) vs. HI (mg HC/g TOC) of the $\mathrm{K}_{1} \mathrm{yc}$ (according to [35]).

25]. In the $K_{1} y c, K_{1}$ sh, and $K_{1} h$, thick organic-rich mudstones with a high thermal maturity have been proven to be the effective source for the gas. Meanwhile, fine sandstone, siltstone, conglomerate, and volcanic rocks formed during volcanic activity are widely spread in the $\mathrm{K}_{1} \mathrm{yc}$, $\mathrm{K}_{1} \mathrm{sh}$, and $\mathrm{K}_{1} \mathrm{~h}$ and act as the reservoir for natural gas accumulation. Thick mudstone developed in the $\mathrm{K}_{2} \mathrm{~d}$ is almost distributed in the entire southern Songliao Basin and could serve as the regional seal, and mudstone layers in each formation mentioned above can serve as the local caprocks [7].

\section{Samples and Methods}

A total of 235 core samples from the $\mathrm{K}_{1} \mathrm{yc}$ were selected in this study (location of sampling well is shown in Figure 1(c)). From these, 97 mudstone samples were selected for Rock-Eval pyrolysis while 16 were chosen for vitrinite reflectance measurements to characterize the source rock. Moreover, 63 samples from the volcanic and 75 from the 


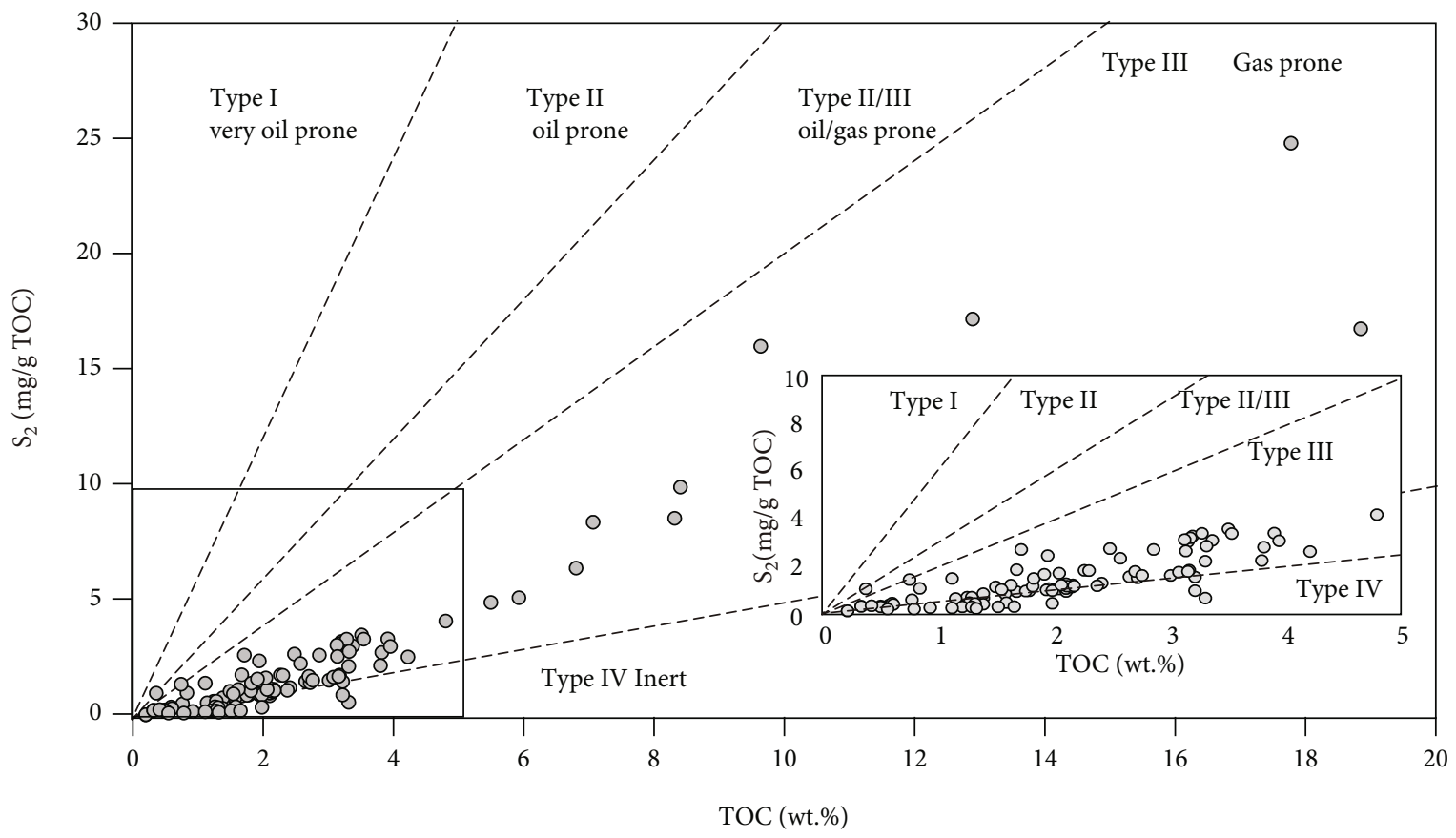

FIgURE 5: The TOC versus $S_{2}$ plot for the $\mathrm{K}_{1} \mathrm{yc}$ source rock samples (according to [36]).

tight sandstone were tested to characterize petrophysical properties of the reservoir. Thin sections were prepared from all reservoir samples and analyzed by using a petrographic microscope Leica DM2700P to observe pore types.

A total of 97 core samples were pulverized to 100 -mesh screen in preparation for geochemical analysis and TOC measurement. The TOC was measured using a LECO CS-230 analyzer, and programmed pyrolysis was performed using a Rock-Eval 6 plus analyzer to obtain $S_{1}$ (free hydrocarbons), $S_{2}$ (petroleum generated by pyrolysis), and $T_{\max }$ (the temperature at peak evolution) by default method $[29,30]$.

Vitrinite reflectance $\left(R_{\mathrm{o}}\right)$ was measured using a microphotometer, and this analysis was performed at the Geochemistry Laboratory of the Northeast Petroleum University. Analysis was performed with an oil immersion objective under normal white light at a wavelength of $546 \mathrm{~mm}$. A mean value was calculated for each sample on the basis of 12-20 measurements on vitrinite [18].

Porosity of core samples (63 volcanic and 75 tight sandstone) was done using core test system AP608 analyzer at Jilin University. The samples were drilled in cylinders with the size of $1^{\prime \prime} \times 4^{\prime \prime}$, vacuum-dried at $180^{\circ} \mathrm{C}$, and then analyzed using a minipermeameter for air permeability measurements by nitrogen (air). The experimental temperature and humidity were $24^{\circ} \mathrm{C}$ and $35 \%$, respectively [31].

\section{Results}

4.1. Geochemistry of Source Rock. Total organic carbon (TOC) in the source rocks of the Yingcheng Formation ranges from 0.22 wt.\% to $18.85 \mathrm{wt} . \%$, with an average value of 3.24 wt. \%, of which $85.6 \%$ is higher than 1.0 wt.\%, and $60.8 \%$ is higher than $2.0 \mathrm{wt} . \%$, in 97 samples that were tested (Table 1). Pyrolysis data was used to determine the type of organic matter following geochemical charts. According to Figures 4 and 5, the pyrolysis data of source rocks plotted in the van Krevelen diagram (HI vs. $T_{\max }$ and $S_{2}$ vs. TOC) are pointing to type III, and a small portion of type IV inert organic matter. Therefore, the organic matter type of the source rocks of the Yingcheng Formation is type III, which dominantly generates gas. The samples with abnormal $T_{\max }$ which is demonstrated in Figure 4 have relatively higher PI index, indicating the presence of bitumen remanence in shale samples.

The distribution of potential hydrocarbon generation capacity $\left(S_{1}+S_{2}\right)$ ranges from 0.16 to $29.06 \mathrm{mg} / \mathrm{g}$, with an average of $6.86 \mathrm{mg} / \mathrm{g}$, among which $35.1 \%$ are higher than $6 \mathrm{mg} / \mathrm{g}$, and $14.4 \%$ are higher than $20 \mathrm{mg} / \mathrm{g}$. An overview of the samples exhibits that they generally represent a poor to good source rock (Figure 6(a)). The HI vs. TOC plot explains that most of the samples are located in the regions of very little to questionable gas (Figure 6(b)). Only parts of the samples are demonstrating to be a good source rock and to have fair gas generation potential with lower $S_{2}$ at the higher maturations (Figure 6).

4.2. Maturation of Organic Matter. The maximum pyrolysis temperature $\left(T_{\max }\right)$ of the source rocks of the Yingcheng Formation was measured between $329^{\circ} \mathrm{C}$ and $570^{\circ} \mathrm{C}$, while most values are more than $470^{\circ} \mathrm{C}$, inferring that the source rocks of the Yingcheng Formation are over mature in the gas generation window with the exclusion of the abnormal data under $400^{\circ} \mathrm{C}$ (Figure $7(\mathrm{a})$ ). The measured vitrinite reflectance $\left(R_{\mathrm{o}}\right)$ values of source rocks in the Yingcheng Formation is positively correlated with the burial depth and increases as the formation becomes deeper (Figure $7(b)$ ). Among these 16 samples that were inspected for $R_{\mathrm{o}}$, except two that are shallower, the $R_{\mathrm{o}}$ was found more than $1.4 \%$, 


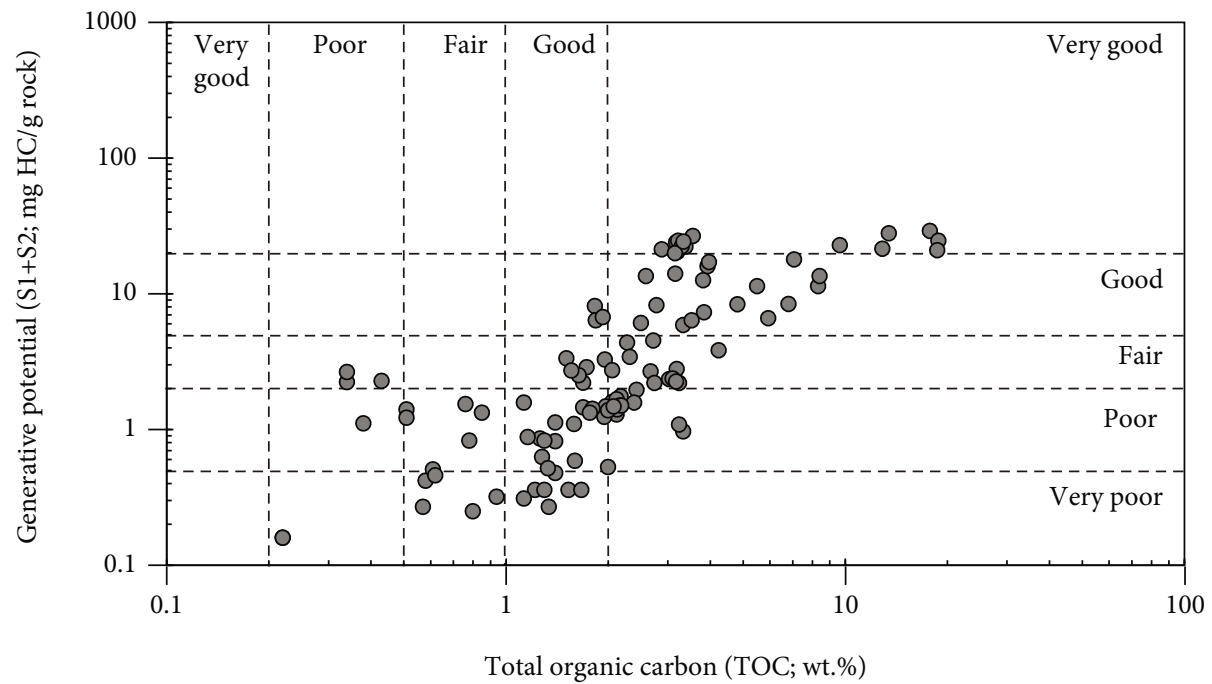

(a)

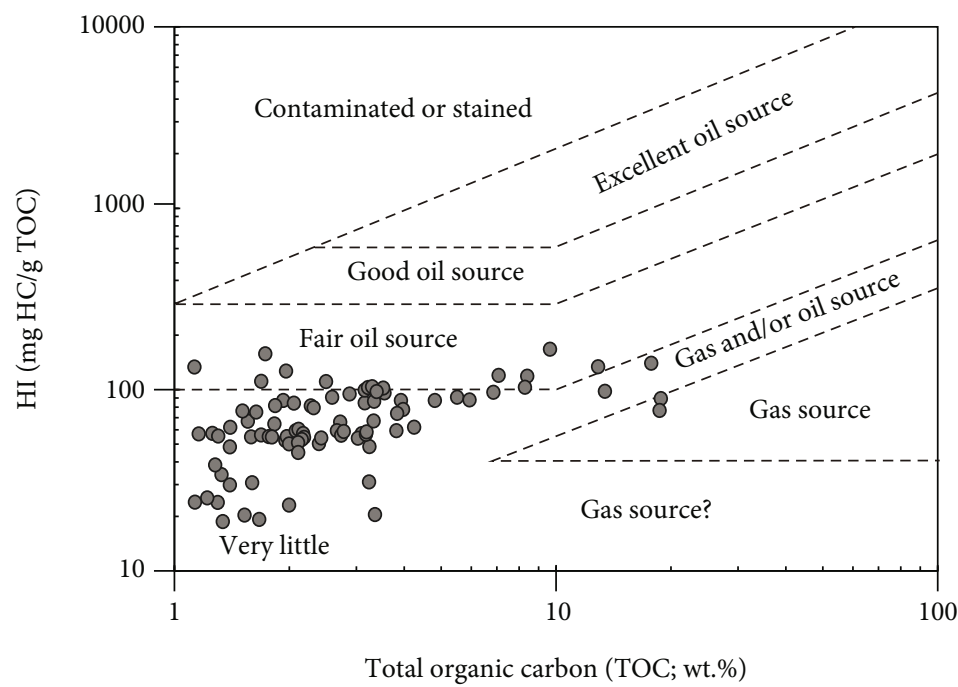

(b)

Figure 6: (a) Plot of total organic carbon (TOC) vs. generative potential $\left(S_{1}+S_{2}\right)$ of the $\mathrm{K}_{1} \mathrm{yc}$ (according to [37]). (b) Plot of TOC vs. HI of the $\mathrm{K}_{1} \mathrm{yc}$ in the study area (according to [38]).

while it appears to be more than $2.0 \%$ for samples buried deeper than $3000 \mathrm{~m}$ (Table 2). Collectively, the organic matter in the source rocks of the Yingcheng Formation in the study area has entered gas generation window and is highly overmatured.

\subsection{Petrophysical Properties}

4.3.1. Volcanic Reservoir. As shown in Figure 2, volcanic rocks are presenting separate seismic reflections attributes compared to other sedimentary layers, making the interpretation of Yingcheng volcanic rocks based on seismic profiles much easier. Volcanic rocks of the Yingcheng Formation are mainly distributed in the northeast of the study area and are controlled by volcanic activities. Their thickness varies from 0 to $400 \mathrm{~m}$ and can reach more than $700 \mathrm{~m}$ locally (Figure 8). The porosity of the volcanic reservoir rocks of the Yingcheng Formation in the study area is between $3.0 \%$ and $14.8 \%$, with an average value of $7.3 \%$. The porosity distribution is approximately normal, with the main peak around 5\%-8\%, which also accounts for $74.6 \%$ of the entire samples. The permeability of the samples were measured between 0.0004 and $2.52 \mathrm{mD}$, while the 0.001 to $0.01 \mathrm{mD}$ interval accounts for $43 \%$ of the total tested samples.

The pore type of volcanic reservoir rocks is complex and varies but can roughly be divided into three types: (1) primary pores, (2) secondary pores, and (3) fractures based on observations on thin sections. The dominant type is secondary pores, mainly feldspar dissolution pores, which are mostly developed in tuff (Figure 9(a)). Moreover, fractures that are formed by the structural stress are more dominant in dacite in the study area (Figures 9(b) and 9(c)) and occasionally observed in tuff (Figure $9(\mathrm{~d})$ ).

4.3.2. Tight Sandstone Reservoir. Tight sandstone deposition is controlled by changes in the facies, mainly distributed in 

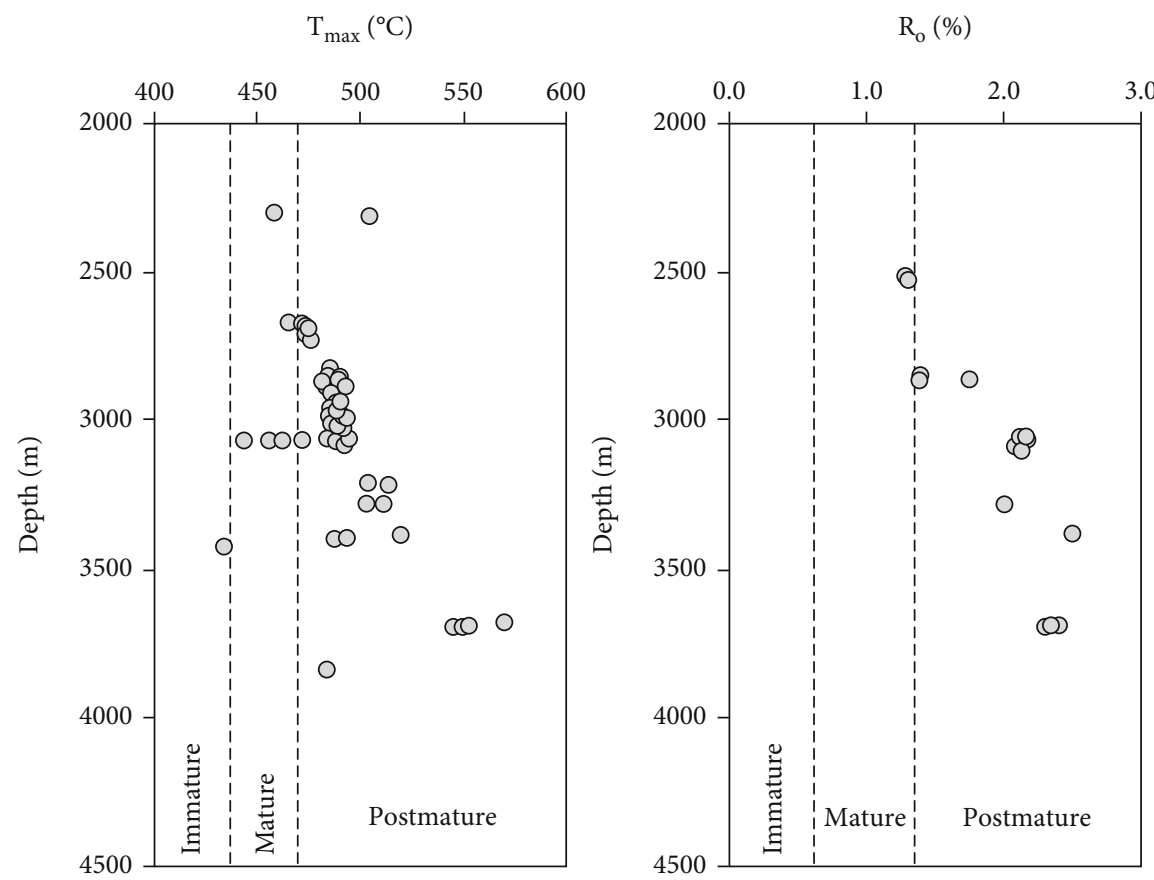

Figure 7: (a) $T_{\max }$ and (b) $R_{\mathrm{o}}$ versus depth for the $\mathrm{K}_{1} \mathrm{yc}$ source rocks samples. Thermal maturity zones are divided according to Peters and Cassa [39].

TABLE 2: Results of vitrinite reflectance experiment.

\begin{tabular}{lcccc}
\hline Well name & Depth $(\mathrm{m})$ & $R_{\mathrm{o}}(\%)$ & Num. measu. & SD \\
\hline DS111 & 2858.2 & 1.39 & 20 & 0.16 \\
DS111 & 2859.2 & 1.76 & 19 & 0.04 \\
DS111 & 2861.9 & 1.40 & 20 & 0.14 \\
DS111 & 3056.0 & 2.13 & 20 & 0.15 \\
DS111 & 3063.1 & 2.15 & 20 & 0.11 \\
DS111 & 3063.4 & 2.17 & 20 & 0.14 \\
DS111 & 3377.9 & 2.49 & 20 & 0.16 \\
DS17-6 & 2518.9 & 1.29 & 20 & 0.14 \\
DS17-6 & 2528.0 & 1.31 & 20 & 0.12 \\
DS81 & 3085.4 & 2.12 & 16 & 0.06 \\
DS81 & 3086.0 & 2.08 & 12 & 0.06 \\
DS81 & 3092.0 & 2.15 & 20 & 0.06 \\
DS83 & 3280.6 & 2.01 & 20 & 0.13 \\
DS83 & 3690.2 & 2.38 & 20 & 0.16 \\
DS83 & 3692.3 & 2.31 & 17 & 0.05 \\
DS83 & 3692.3 & 2.40 & 20 & 0.17 \\
\hline
\end{tabular}

$R_{\mathrm{o}}$ : vitrinite reflectance; Num. measu.: number of measured points; SD: standard deviation.

the delta front and plain subfacies in the northeast and northwestern areas of the fault depression, with a thickness of $0-400 \mathrm{~m}$ (Figure 10). The thickness of sandstone facies in the middle of the fault depression is less than $100 \mathrm{~m}$. Furthermore, the porosity of tight sandstone in the Yingcheng Formation in the study area was measured between $0.5 \%$ and $11.2 \%$, with an average value of $5.1 \%$, and its distribu- tion is also approximately uniform. Comparing their porosity with the volcanic reservoir, the distribution of measured porosity values is relatively dispersed, and $2 \%-7 \%$ of porosity constitutes $69.3 \%$ of total collected data. In addition, the permeability of the samples was found to vary between 0.0008 and $3.17 \mathrm{mD}$, with the peak at $0.001 \mathrm{mD}$. Considering thin section analysis, the reservoir space in the study area is mainly intergranular pores, with a small amount of intragranular pores and microfractures (Figure 11).

\section{Discussion}

5.1. Volcanic Effects on Hydrocarbon Generation. Volcanic intrusions have increased the temperature and pressure of the Yingcheng Formation and promoted the generation and expulsion of hydrocarbon in the source rocks [32]. Bulk geochemical data sets in this study show that deeply buried source rocks of the Yingcheng Formation in the Songliao Basin are widely developed and have good hydrocarbon generation potential. These source rocks are mostly type III kerogen with high TOC content. Additionally, measured $R_{\mathrm{o}}$ is generally greater than $1.4 \%$, which is overmature, and on the onset of gas generation window. It is speculated that late volcanic intrusions provided sufficient heat source for the transformation of organic matter and caused the generation of natural gas in large quantities. The magmatic thermal field not only improves the geothermal gradient of the basin but also enhances the degree of thermal evolution of the organic matter compensating for the pressure and burial depth. This makes the threshold of gas generation to happen at the shallower depth, enhancing hydrocarbon generation [33]. In the volcanic gas reservoirs, the bitumen is common in micro fractures (Figures 9(b)-9(d)), referring to the 


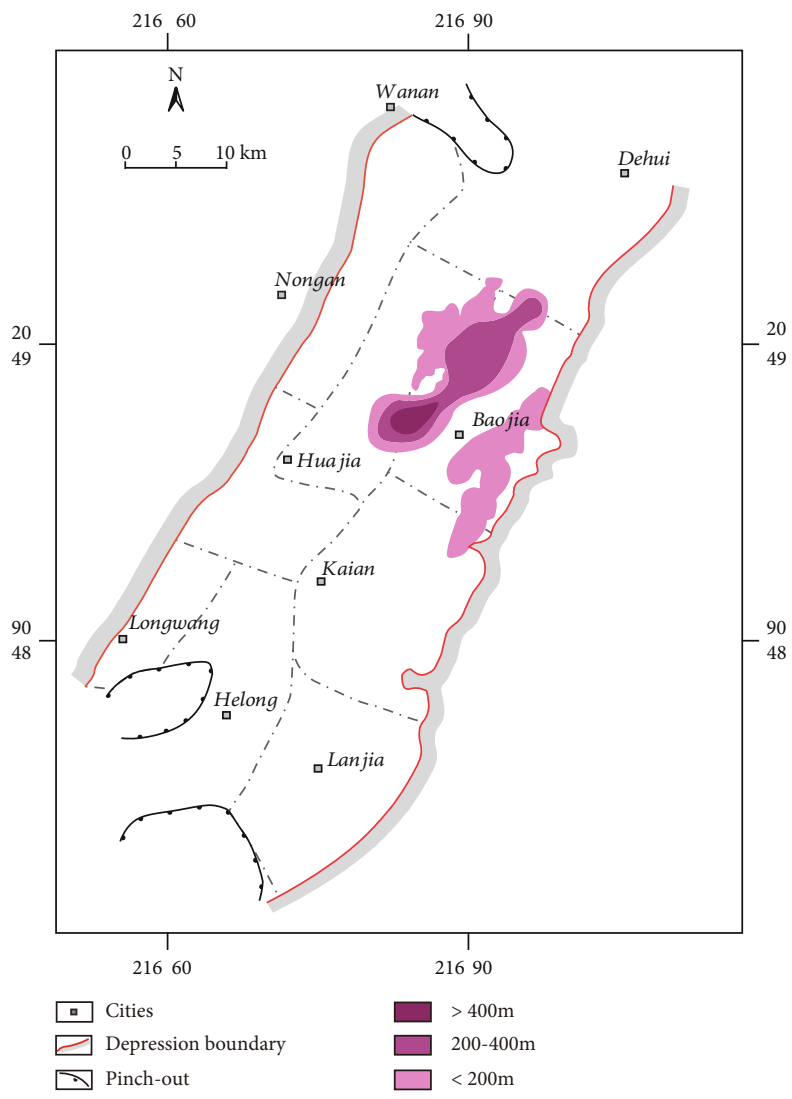

Figure 8: Distribution of volcanic rock reservoir of the $\mathrm{K}_{1} \mathrm{yc}$.

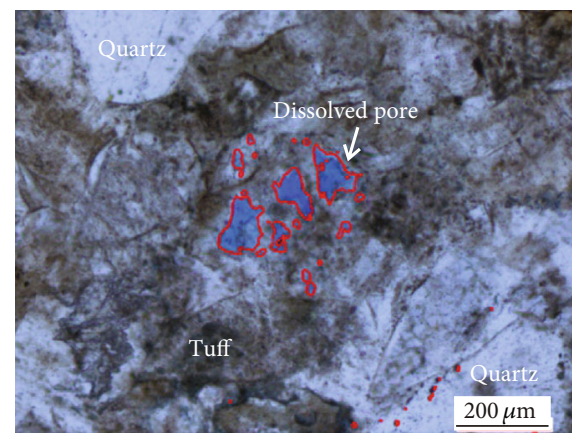

(a)

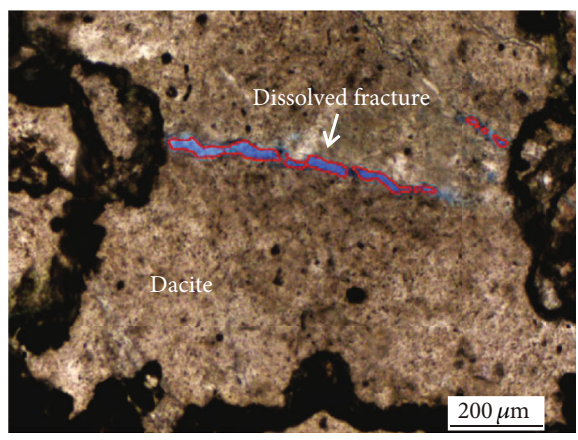

(c)

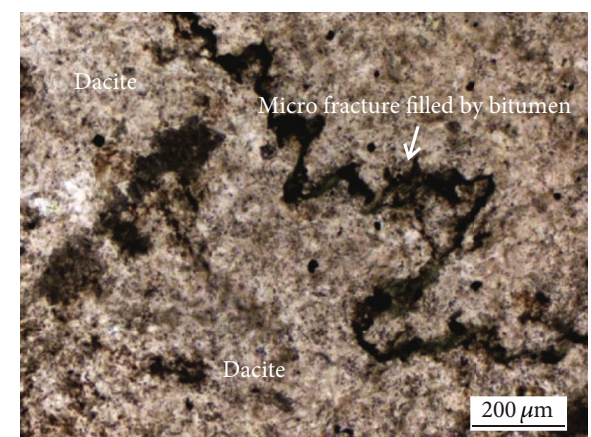

(b)

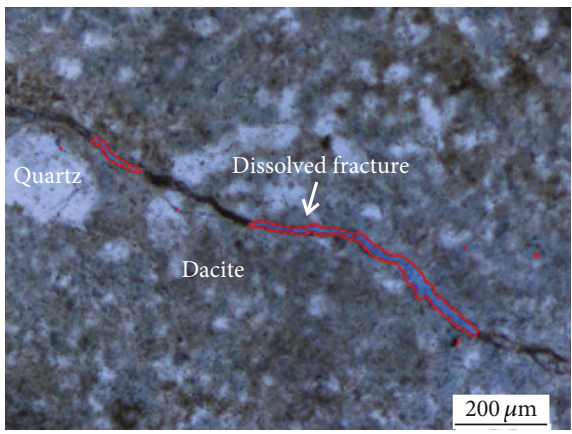

(d)

FIGURE 9: Thin section observed by plane-polarized and light perpendicular-polarized light for volcanic reservoir samples for the $\mathrm{K}_{1} \mathrm{yc}$. (a) $2700.0 \mathrm{~m}$, tuff; (b) $2240.0 \mathrm{~m}$, dacite; (c) $2240.9 \mathrm{~m}$, dacite; (d) $2700.0 \mathrm{~m}$, tuff. 


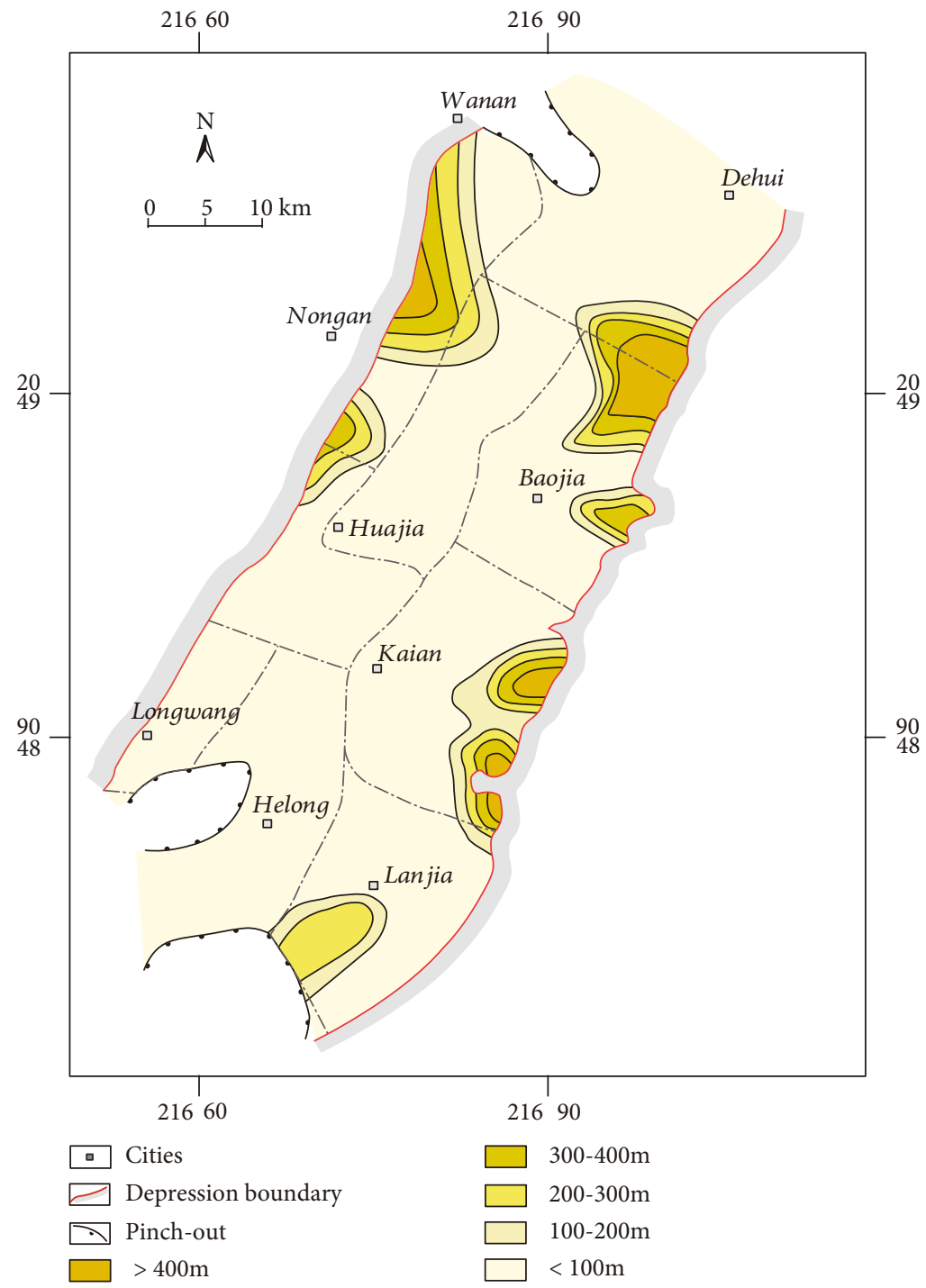

FIgURE 10: Distribution of tight sandstone reservoir of the $\mathrm{K}_{1} \mathrm{yc}$.

abnormal high maturity which is consistent with the high paleo heat flow during the synrift phase [25]. This was caused by the upwelling of mantle plumes and the thinning of the crust, which were accompanied with volcanic activates before the Late Mesozoic-Cenozoic rapid cooling [34].

5.2. Pore Genesis of Reservoir. Based on the inspection of thin sections (Figure 9), the volcanic reservoir of the Yingcheng Formation is mainly tuff and dacite, and the pores are mainly from mineral dissolution to create pores and microfractures. As shown in Figure 9, dissolution pores in the volcanic reservoirs such as tuff or dacite are mostly isolated and poorly connected. At the same time, the dissolution microfractures have a short extent, small width and irregularity, and limited in scope and number. Observation of thin sections also revealed the presence of asphaltene filling in the cracks.

Tight sandstone reservoir of the Yingcheng Formation is generally dominated by intragranular dissolution pores, accounting for $89 \%$ of the total pores (Figure 11). Among them, feldspar dissolution pores are the most developed ones, accounting for 35\%, followed by lithic dissolution pores with $20 \%$, intergranular dissolution pores $19 \%$, and tuffaceous dissolution pores constituting $15 \%$ of the entire measured data. Likewise, a small number of intergranular pores, with $8 \%$ of the total pores measured, can also be responsible for a certain number of microfractures, around $3 \%$. The intergranular dissolution pores are filled with autogenous albite, felsic particles, coniferous flake chlorite, and a small amount of illite and other clay minerals. The percentage of total surface porosity observed under the microscope is generally about $3 \%-10 \%$. This kind of reservoir space is dominated by dissolved pores, nanoscale throat and underdeveloped reservoir characteristics, poor pore connectivity, easy-to-form isolated pores, resulting in "isolated pore space," and dense characteristics of the reservoir with low permeability overall.

The porosity of tight sandstone is much less than the volcanic rocks at the same depth (Figure 12(a)). The porosity and permeability of sandstones has an obvious decreasing 


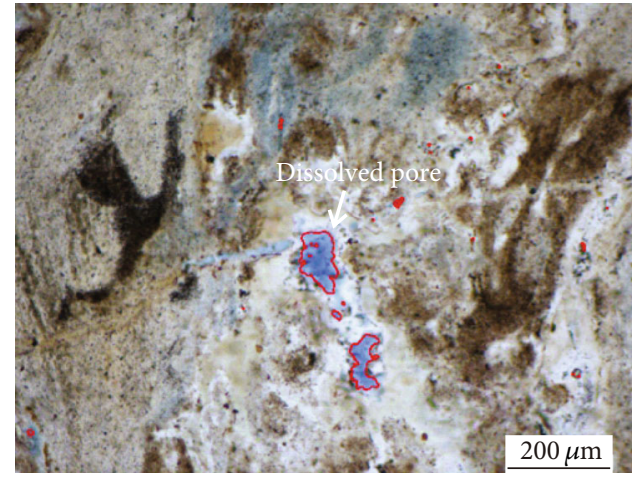

(a)

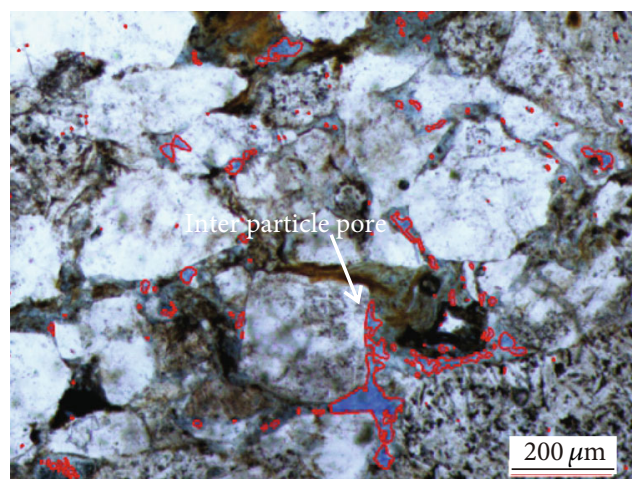

(c)

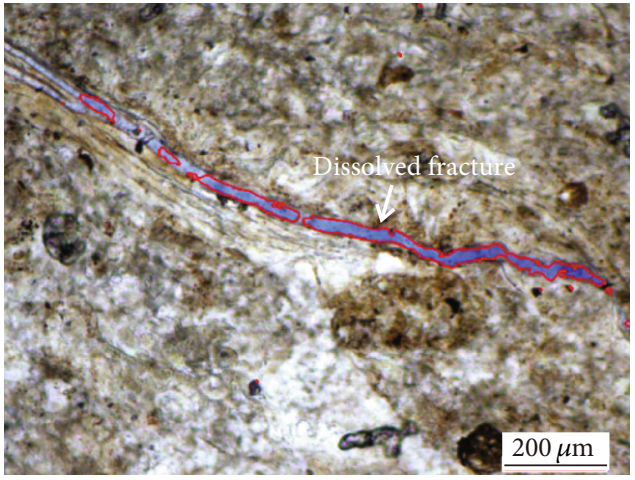

(b)

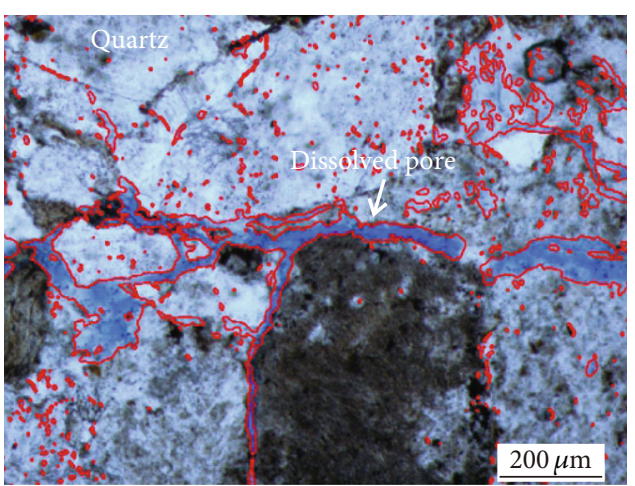

(d)

FIgURE 11: Thin section observed by plane-polarized and light perpendicular-polarized light for tight sandstone reservoir samples for the $\mathrm{K}_{1}$ yc. (a) $2522 \mathrm{~m}$, tuffaceous sandstone; (b) $2543 \mathrm{~m}$, tuffaceous sandstone; (c) $2803.5 \mathrm{~m}$, tuffaceous sandstone; (d) $2912.5 \mathrm{~m}$, tuffaceous sandstone ((c) and (d) are referenced from [28]).

trend in the range of 2000-4500 m, which is caused by the compaction (Figure 12(b)). However, the porosity and permeability of volcanic reservoirs do not change much with depths, and the values are relatively concentrated, proving that compaction has little influence on the quality of the volcanic reservoir. In comparison with tight sandstone reservoir, the porosity of volcanic rock is relatively similar at shallower depth but generally improves with depth. The permeability of volcanic rocks is less than tight sandstones, but again it enhances with depth. That confirms how the effects of compaction on sandstones and volcanic rocks can be different, causing the sandstone to always have relatively better porosity and permeability at shallower depth, though it is important that one does not overlook the improvement of reservoir properties in the volcanic rock, too, as the formation gets deeper.

5.3. Gas Accumulation Model in Volcanic Area. During the formation of the Yingcheng Formation in the study area, the basin was under extension [7]; thus, the controlling depression fault expanded eastward, and the sedimentary area gradually expanded, accompanied by volcanic activities for the entire period. The early subsidence center of the Yingcheng Formation is close to the boundary fault, making the deep extension area small. Moreover, volcanic activity mainly happened in the eastern gentle slope of the basin, which controlled sedimentation in the eastern boundary as well. Likewise, volcanic erosions provided additional sediment supply for the basin. In the middle stages of the
Yingcheng Formation, the depocenter migrated northward to the east, the deep depression area expanded, and the volcanic rocks in the eastern gentle slope area generally eroded. At the end of the deposition of the Yingcheng Formation, the basin shrunk, and the deeper depression area was distributed along the boundary faults. Besides, the stratigraphic distribution range was large with limited thickness, and as the volcanism was strengthened, it affected the entire basin. This caused the strata to get dispersed between the volcanically active areas and the control-depression fault. Therefore, the reservoirs are scattered in the middle and upper parts of the Yingcheng Formation, which made the relationship between the source and the reservoir rocks stronger.

During the earlier phases of volcanic eruption, larger volcanic bodies developed, which controlled the lateral boundaries of the trough of the Yingcheng Formation, to form an updip lateral block due to the tectonic activity that was later followed. The volcanic rocks mainly from tuff in the Yingcheng Formation formed during the middle phases of volcanism have constant thickness (ranging from 80 to $150 \mathrm{~m}$, and more than $200 \mathrm{~m}$ locally) and wide lateral distribution, which played the role of the regional caprock [28]. These two volcanic activities promoted the formation of large traps and played a vital role in gas enrichment and preservation. Furthermore, the tuff layer is very dense, is free of fractures, and does not intrude and damage the gas reservoir, sealing the entire tight sandstone reservoir underneath. The early and middle volcanism surrounded the entire Yingcheng 


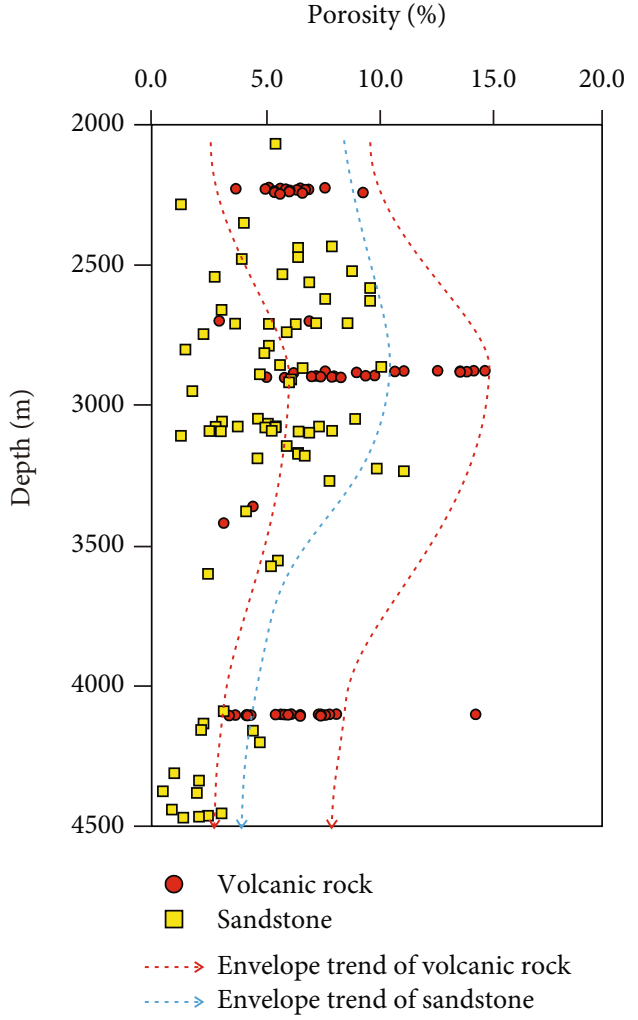

(a)

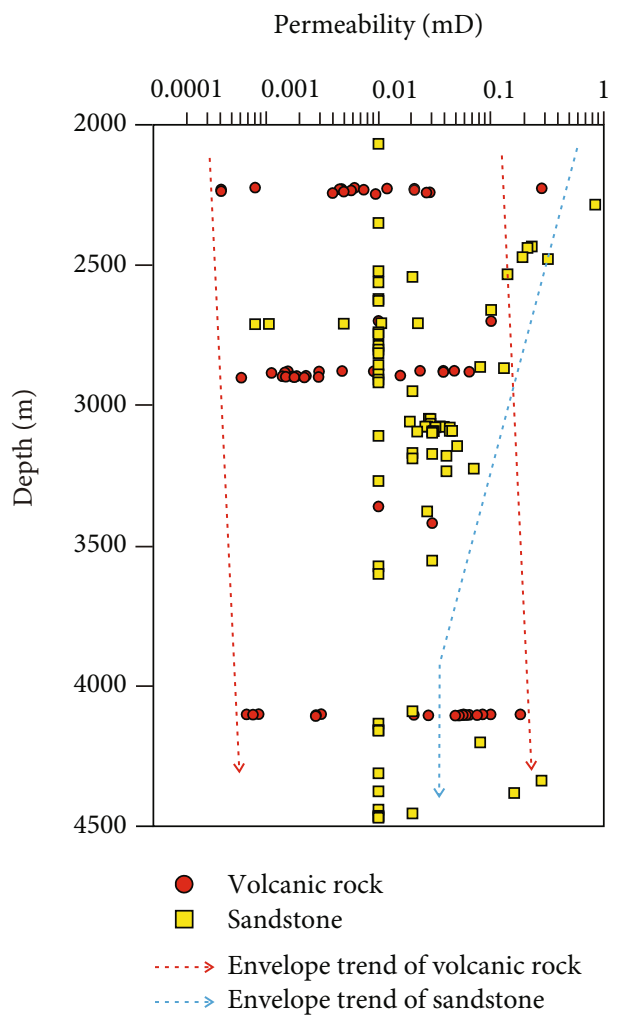

(b)

FIGURE 12: (a) Porosity and (b) permeability versus the depth of volcanic rock reservoir and tight sandstone reservoir samples for the $\mathrm{K}_{1} \mathrm{yc}$.

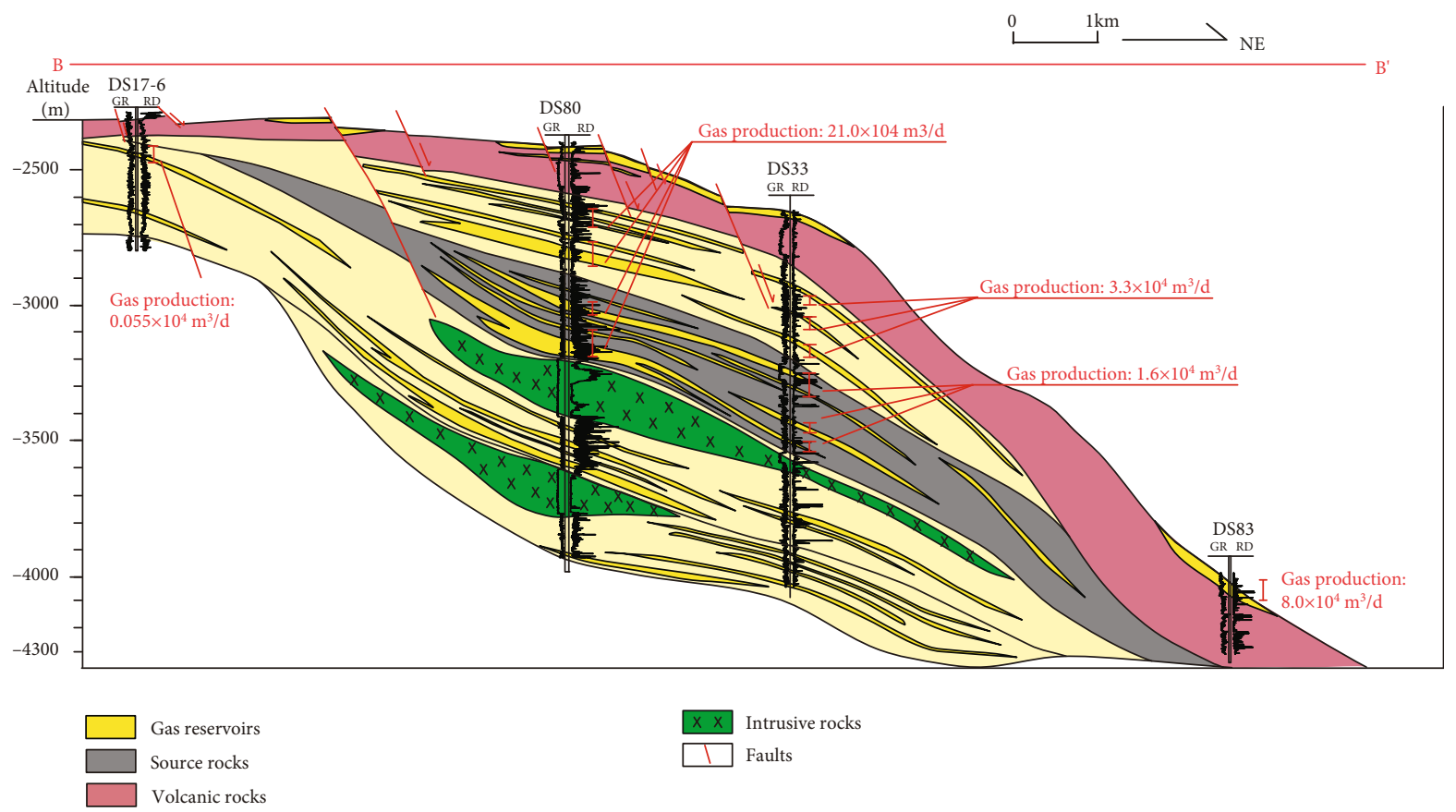

FIGURE 13: Cross-section of gas accumulation in the $\mathrm{K}_{1} \mathrm{yc}$; location of the profile is shown in Figure 1. In this section, suitable gas productive zones in the volcanic rock reservoir and tight sandstone reservoir are displayed (modified from [28]). 
Formation and supported the formation of tight sandstone gas traps. The above two volcanic activities formed one block and one cap, which provided favorable trap conditions for tight sandstone gas reservoirs (Figure 13).

On the other hand, volcanic rocks in some areas are replaced with sandstone bodies, to become complementary reservoir space. This combination of tight sandstone and volcanic gas reservoirs formed in the same horizon also produced economic quantities of gas. For example, well DS80 showed $21.0 \times 10^{4} \mathrm{~m}^{3} / \mathrm{d}$ flow rate in the $2650-3200 \mathrm{~m}$ interval, well DS33, $3.3 \times 10^{4} \mathrm{~m}^{3} / \mathrm{d}$ and $1.6 \times 10^{4} \mathrm{~m}^{3} / \mathrm{d}$ in two separate intervals, and well DS83, $8.0 \times 10^{4} \mathrm{~m}^{3} / \mathrm{d}$ of high-yielding flow in the upper volcanic zone of the reservoir (Figure 13).

\section{Conclusion}

(1) The organic carbon content of the source rocks of the Yingcheng Formation in Dehui fault depression varies from 0.22 wt. $\%$ to 18.85 wt. $\%$, with an average of $3.05 \mathrm{wt} . \%$. The distribution of potential hydrocarbon generation $\left(S_{1}+S_{2}\right)$ was found from 0.16 to $29.06 \mathrm{mg} / \mathrm{g}$, with an average of $6.21 \mathrm{mg} / \mathrm{g}$. Additionally, organic matter is mainly type III and at the high-overmaturity, representing favorable conditions for gas generation

(2) The thickness of volcanic reservoir in the study area is $0-400 \mathrm{~m}$, the porosity is $3.0 \%-14.8 \%$, the permeability is $0.0004-2.52 \mathrm{mD}$, and pore types are mainly secondary dissolved pores and fractures. Moreover, the thickness of the tight sandstone reservoir is 0$400 \mathrm{~m}$, the porosity is $0.5 \%-11.2 \%$, and the permeability is $0.0008-3.17 \mathrm{mD}$. Pore types are generally intergranular pores, with a small amount of intragranular pores and microfractures

(3) Late volcanic activity of the Yingcheng Formation in the study area provided sufficient heat source for the organic matter transformation and promoted the generation of natural gas in large quantities

(4) The petrophysical properties of the tight sandstone reservoir deteriorated significantly with depth and are affected by compaction notably, while the petrophysical properties of volcanic reservoir do not vary much as the formation get deeper representing more homogeneous characteristics. At the same time, secondary pores formed by late dissolution of pyroclasts formed by volcanic activities also provided storage space for gas accumulation

(5) Volcanic rocks that are formed during the early and middle phases of the Yingcheng Formation development occupied the sedimentary space, which worked against the deposition of sand bodies to some extent. However, volcanic rocks became regional seals as part of the tight sandstone gas trap. Finally, the combination of volcanic rocks and tight sandstones has created a complex petroleum system for the accumulation and preservation of gas in the basin.

\section{Data Availability}

All data sets are included in the manuscript.

\section{Conflicts of Interest}

The authors declare that they have no conflicts of interest.

\section{Acknowledgments}

This study is supported by the Science and Technology Project of Heilongjiang Province (No. 2020ZX05A01) and National Major Project (Nos. 2016ZX05047-005-006 and 2016ZX05027-002-007).

\section{References}

[1] IEA (International Energy Agency), World Energy Outlook 2019, IEA, Washington D C, 2019.

[2] B. Dudley, BP Statistical Review of World Energy, BP Statistical Review, London, UK, 2018.

[3] C. N. Zou, Z. Yang, D. B. He et al., "Theory, technology and prospects of conventional and unconventional natural gas," Petroleum Exploration and Development, vol. 45, no. 4, pp. 604-618, 2018.

[4] C. N. Zou, R. Zhu, K. Liu et al., "Tight gas sandstone reservoirs in China: characteristics and recognition criteria," Journal of Petroleum Science and Engineering, vol. 88-89, no. 2, pp. 8291, 2012.

[5] H. Jia, H. Ji, L. Wang, D. Yang, P. Meng, and C. Shi, "Tectonosedimentary and hydrocarbon potential analysis of rift-related successions in the Dehui Depression, Songliao Basin, Northeastern China," Marine and Petroleum Geology, vol. 76, pp. 262-278, 2016.

[6] F. Jiang, R. H. Cheng, B. T. Ruan, B. Lin, Z. J. Xu, and Z. C. Li, "Formation mechanism of volcanic reservoirs within a volcanostratigraphic framework: the case of the Wangfu fault depression in the Songliao Basin, China," Marine and Petroleum Geology, vol. 84, pp. 160-178, 2017.

[7] B. Liu, S. He, L. Meng, X. Fu, L. Gong, and H. Wang, "Sealing mechanisms in volcanic faulted reservoirs in Xujiaweizi extension, Northern Songliao Basin, Northeastern China," AAPG Bulletin, vol. 105, no. 8, pp. 1721-1743, 2021.

[8] B. Liu, Y. Yang, J. Li, Y. Chi, J. Li, and X. Fu, "Stress sensitivity of tight reservoirs and its effect on oil saturation: a case study of Lower Cretaceous tight clastic reservoirs in the Hailar Basin, Northeast China," Journal of Petroleum Science and Engineering, vol. 184, p. 106484, 2020.

[9] X. Luo, S. Gong, F. J. Sun, Z. H. Wang, and J. S. Qi, "Effect of volcanic activity on hydrocarbon generation: examples in Songliao, Qinshui, and Bohai Bay Basins in China," Journal of Natural Gas Science \& Engineering, vol. 38, pp. 218-234, 2017.

[10] Z. Q. Feng, "Volcanic rocks as prolific gas reservoir: a case study from the Qingshen gas field in the Songliao Basin, NE China," Marine and Petroleum Geology, vol. 25, no. 4-5, pp. 416-432, 2008.

[11] J. Li, Z. Yang, S. Wu, and S. Pan, "Key issues and development direction of petroleum geology research of source rock strata in China," Advances in Geo-Energy Research, vol. 5, no. 2, pp. 121-126, 2021. 
[12] C. Wang, L. Liu, Y. H. Wang et al., "Recognition and tectonic implications of an extensive Neoproterozoic volcano- sedimentary rift basin along the southwestern margin of the Tarim Craton, northwestern China," Precambrian Research, vol. 257, pp. 65-82, 2015.

[13] E. A. Khalaf, "Variations in eruptive style and depositional processes of Neoproterozoic terrestrial volcano-sedimentary successions in the Hamid area, North Eastern Desert, Egypt," Journal of African Earth Sciences, vol. 83, pp. 74-103, 2013.

[14] M. K. Azer and E. S. Farahat, "Late Neoproterozoic volcanosedimentary successions of Wadi Rufaiyil, southern Sinai, Egypt: a case of transition from late- to post-collisional magmatism," Journal of Asian Earth Sciences, vol. 42, no. 6, pp. 1187-1203, 2011.

[15] J. N. J. Visser and N. J. Grobler, "Syndepositional volcanism in the Rietgat and arenaceous Bothaville Formations, Ventersdorp Supergroup (late Archaean-early Proterozoic), in South Africa," Precambrian Research, vol. 30, no. 2, pp. 153-174, 1985.

[16] J. Cai, H. Hajibeygi, J. Yao, and S. M. Hassanizadeh, “Advances in porous media science and engineering from InterPore2020 perspective," Advances in Geo-Energy Research, vol. 4, no. 4, pp. 352-355, 2020.

[17] B. Liu, D. Yan, X. Fu, Y. Lü, L. Gong, and S. Wang, "Investigation of geochemical characteristics of hydrocarbon gas and its implications for Late Miocene transpressional strength - a study in the Fangzheng Basin, Northeast China," Interpretation, vol. 6, no. 1, pp. T83-T96, 2018.

[18] B. Liu, A. Bechtel, R. F. Sachsenhofer, D. Gross, R. Gratzer, and $\mathrm{X}$. Chen, "Depositional environment of oil shale within the second member of Permian Lucaogou Formation in the Santanghu Basin, Northwest China," International Journal of Coal Geology, vol. 175, pp. 10-25, 2017.

[19] Y. S. Pan, Z. L. Huang, T. J. Li, X. B. Guo, X. F. Xu, and $\mathrm{X}$. Chen, "Environmental response to volcanic activity and its effect on organic matter enrichment in the Permian Lucaogou Formation of the Malang Sag, Santanghu Basin, Northwest China," Palaeogeography, Palaeoclimatology, Palaeoecology, vol. 560, article 110024, 2020.

[20] S. C. George, "Effect of igneous intrusion on the organic geochemistry of a siltstone and an oil shale horizon in the Midland Valley of Scotland," Organic Geochemistry, vol. 18, no. 5, pp. 705-723, 1992.

[21] B. K. T. Simoneit, S. Bernner, K. E. Peters, and I. R. Kaplan, "Thermal alteration of Cretaceous black shale by diabase intrusions in the Eastern Atlantic-II. Effects on bitumen and kerogen," Geochimica et Cosmochimica Acta, vol. 45, no. 9, pp. 1581-1602, 1981.

[22] Y. G. Sun, J. M. Fu, D. H. Liu, G. Y. Sheng, Z. Y. Chen, and T. S. $\mathrm{Wu}$, "Effects of volcanic activity on organic matter evolution and its significance on petroleum," Chinese Scicence Bulletin, vol. 40, pp. 1019-1022, 1995.

[23] B. Liu, J. Sun, Y. Zhang et al., "Reservoir space and enrichment model of shale oil in the first member of Cretaceous Qingshankou Formation in the Changling sag, southern Songliao Basin, NE China," Petroleum Exploration and Development, vol. 48, no. 3, pp. 608-624, 2021.

[24] P. J. Wang, Y. G. Ren, X. L. Shan, S. B. Sun, C. B. Wan, and W. H. Bian, "The Cretaceous volcanic succession around the Songliao Basin, NE China: relationship between volcanism and sedimentation," Geological Journal, vol. 37, no. 2, pp. 97-115, 2002.
[25] Z. J. Xu, S. Jiang, L. F. Liu et al., "Natural gas accumulation processes of tight sandstone reservoirs in deep formations of Songliao Basin, NE China," Journal of Natural Gas Science and Engineering, vol. 83, pp. 103610-103620, 2020.

[26] H. F. Tang, X. Y. Zhao, X. Liu, C. X. Zhu, W. H. Qu, and W. H. Bian, "Filling characteristics, reservoir features and exploration significance of a volcanostratigraphic sequence in a halfgraben basin - a case analysis of the Wangfu Rift Depression in Songliao Basin, NE China," Marine and Petroleum Geology, vol. 113, article 104128, 2020.

[27] H. F. Tang, X. Y. Zhao, M. L. Shao, X. D. Sun, Y. Zhang, and P. Cryton, "Reservoir origin and characterization of gas pools in intrusive rocks of the Yingcheng Formation, Songliao Basin, NE China," Marine and Petroleum Geology, vol. 84, pp. 148159, 2017.

[28] F. C. Zeng, C. M. Zhang, Z. S. Wei et al., "Main enrichment controlling factors and reservoir characteristics of tight sandstone gas under the influence of volcanic activity," Acta Geologica Sinica, vol. 95, no. 3, pp. 895-912, 2021.

[29] J. Espitalié, F. Marquis, and I. Barsony, "Geochemical logging," in Analytical Pyrolysis, K. J. Voorhess, Ed., pp. 53-79, Butterworths, Boston, 1984.

[30] B. T. Tissot and D. H. Welte, Petroleum Formation and Occurrences, Springer Verlag, Berlin, second edition, 1984.

[31] S. Huang, Y. Wu, X. Meng, L. Liu, and W. Ji, “Recent advances on microscopic pore characteristics of low permeability sandstone reservoirs," Advances in Geo-Energy Research, vol. 2, no. 2, pp. 122-134, 2018.

[32] L. D. Sun, C. H. Yin, C. Liu et al., "Geological characteristics and exploration significance of high-quality source rocks in Yingcheng Formation, Songliao Basin," Acta Petrolei Sinica, vol. 40, no. 10, pp. 1172-1179, 2019.

[33] M. Wang, S. F. Lu, H. T. Xue, J. Wu, and D. W. Liu, "The effects of magmatic intrusions on the maturation of organic matter and its numerical simulation," Acta Petrologica Sinica, vol. 26, pp. 177-184, 2010.

[34] Y. H. Cheng, S. Y. Wang, Y. Li et al., "Late CretaceousCenozoic thermochronology in the southern Songliao Basin, NE China: New insights from apatite and zircon fission track analysis," Journal of Asian Earth Sciences, vol. 160, pp. 95106, 2018.

[35] K. S. Jackson, P. J. Hawkins, and A. J. R. Bennett, "Regional facies and geochemical, evaluation of southern Denison Trough," The APEA Journal, vol. 20, pp. 143158, 1985.

[36] F. F. Langford and M. M. Blanc-Valleron, "Interpreting RockEval pyrolysis data using graphs of pyrolizable hydrocarbons vs. total organic carbon (1)," American Association of Petroleum Geologists Bulletin, vol. 74, pp. 799-804, 1990.

[37] K. E. Peters, "Guidelines for evaluating petroleum source rock using programmed pyrolysis," AAPG, vol. 70, pp. 318-329, 1986.

[38] K. Jackson, P. Hawkins, and A. Bennett, "Regional facies and geochemical evaluation of the southern Denison Trough, Queensland," The APPEA Journal, vol. 20, pp. 143-158, 1980.

[39] K. E. Peters and M. R. Cassa, "Applied source rock geochemistry," in The Petroleum System-from Source to Trap, L. B. Magoon and W. G. Dow, Eds., pp. 93-120, AAPG Memoir; American Association of Petroleum Geologists, Tulsa, OK, 1994. 